\title{
The interactions of physical activity, exercise and genetics and their associations with bone mineral density: implications for injury risk in elite athletes
}

\author{
Adam J. Herbert ${ }^{1}$ (D) Alun G. Williams ${ }^{2,5}$. Philip J. Hennis ${ }^{3} \cdot$ Robert M. Erskine $^{4,5}$. Craig Sale $^{3}$. Stephen H. Day ${ }^{6}$. \\ Georgina K. Stebbings ${ }^{2}$
}

Received: 25 May 2018 / Accepted: 4 October 2018 / Published online: 30 October 2018

(C) The Author(s) 2018

\begin{abstract}
Low bone mineral density (BMD) is established as a primary predictor of osteoporotic risk and can also have substantial implications for athlete health and injury risk in the elite sporting environment. BMD is a highly multi-factorial phenotype influenced by diet, hormonal characteristics and physical activity. The interrelationships between such factors, and a strong genetic component, suggested to be around $50-85 \%$ at various anatomical sites, determine skeletal health throughout life. Genome-wide association studies and case-control designs have revealed many loci associated with variation in BMD. However, a number of the candidate genes identified at these loci have no known associated biological function or have yet to be replicated in subsequent investigations. Furthermore, few investigations have considered gene-environment interactions-in particular, whether specific genes may be sensitive to mechanical loading from physical activity and the outcome of such an interaction for BMD and potential injury risk. Therefore, this review considers the importance of physical activity on BMD, genetic associations with BMD and how subsequent investigation requires consideration of the interaction between these determinants. Future research using well-defined independent cohorts such as elite athletes, who experience much greater mechanical stress than most, to study such phenotypes, can provide a greater understanding of these factors as well as the biological underpinnings of such a physiologically "extreme" population. Subsequently, modification of training, exercise or rehabilitation programmes based on genetic characteristics could have substantial implications in both the sporting and public health domains once the fundamental research has been conducted successfully.
\end{abstract}

Keywords Genetics $\cdot$ Bone $\cdot$ Exercise $\cdot$ Polymorphism $\cdot$ Running $\cdot$ Fracture

\begin{tabular}{|c|c|c|c|}
\hline \multicolumn{2}{|c|}{ Abbreviations } & \multirow[t]{2}{*}{ FOSL1 } & \multirow{2}{*}{$\begin{array}{l}\text { FOS-like 1, AP-1 transcription factor } \\
\text { subunit }\end{array}$} \\
\hline AXIN1 & Axin 1 & & \\
\hline BMD & Bone mineral density & GWAS & Genome-wide association studies \\
\hline BGLAP & Bone gamma-carboxyglutamate protein & IGF1 & Insulin-like growth factor 1 \\
\hline $\mathrm{CA}++$ & Intracellular calcium & IL6 & Interleukin 6 \\
\hline CTR & Calcitonin receptor & JUNB & JunB proto-oncogene, AP-1 transcription \\
\hline COMT & Catechol-O-methyltransferase & & factor subunit \\
\hline \multirow[t]{2}{*}{ ERC1 } & ELKS/Rab6-interacting/CAST family & LRP5 & LDL receptor-related protein 5 \\
\hline & member 1 & MMPs & Matrix metallopeptidases \\
\hline \multirow[t]{3}{*}{$\begin{array}{l}\text { ERK1/2 } \\
\text { ESR1 }\end{array}$} & $\begin{array}{l}\text { Extracellular signal-regulated kinase } 1 / 2 \\
\text { Oestrogen receptor } 1\end{array}$ & NHANES & $\begin{array}{l}\text { National Health and Nutrition Examina- } \\
\text { tion Survey }\end{array}$ \\
\hline & & $\mathrm{NF}-\kappa \mathrm{B}$ & Nuclear factor- $\kappa \mathrm{B}$ translocation \\
\hline & & OPG & Osteoprotegerin \\
\hline \multicolumn{2}{|c|}{ Communicated by Michael Lindinger. } & $\mathrm{PGE}_{2}$ & Prostaglandin $\mathrm{E}_{2}$ \\
\hline \multirow{2}{*}{\multicolumn{2}{|c|}{$\begin{array}{l}\square \text { Adam J. Herbert } \\
\text { adam.herbert@bcu.ac.uk }\end{array}$}} & $\mathrm{P} 2 \mathrm{RX} 7$ & Purinergic receptor $\mathrm{P} 2 \mathrm{X} 7$ \\
\hline & & RANK & Receptor activator of nuclear factor $\mathrm{\kappa B}$ \\
\hline
\end{tabular}

Extended author information available on the last page of the article 


\begin{tabular}{|c|c|}
\hline RANKL & $\begin{array}{l}\text { Receptor activator of nuclear factor } \kappa \mathrm{B} \\
\text { ligand }\end{array}$ \\
\hline SFRP4 & Secreted frizzled-related protein 4 \\
\hline SNP & Single nucleotide polymorphism \\
\hline SOST & Sclerostin \\
\hline STARD3NL & $\begin{array}{l}\text { StAR-related lipid transfer domain con- } \\
\text { taining } 3 \mathrm{~N} \text {-terminal like }\end{array}$ \\
\hline TNFSF11 & TNF receptor superfamily member \\
\hline TNFRSF11A & TNF receptor superfamily member $11 \mathrm{a}$ \\
\hline TNFRSF11B & TNF receptor superfamily member $11 \mathrm{~b}$ \\
\hline VDR & $\begin{array}{l}\text { Vitamin } \mathrm{D}\left(1,25 \text {-dihydroxyvitamin } \mathrm{D}_{3}\right) \\
\text { receptor }\end{array}$ \\
\hline WNT5B & Wnt family member $5 \mathrm{~B}$ \\
\hline WNT16 & Wnt family member 16 \\
\hline
\end{tabular}

\section{Introduction}

Low bone mineral density (BMD) is established as a primary predictor of osteoporotic risk and can have substantial implications for athlete health and injury risk in the elite sporting environment. BMD is a highly multi-factorial phenotype influenced by diet, hormonal characteristics as well as physical activity (Darling et al. 2009; Pluijm et al. 2001). Physical activity/exercise reportedly accounts for up to $30 \%$ of the variability in BMD (Valdimarsson et al. 1999) although the exact contribution of physical activity to BMD remains unclear and requires further exploration across various population groups. Following physical activity, osteocytes detect shape and volume changes to increase or decrease the liberation of specific bone mediators, which consequently influences bone formation and resorption (Nakashima et al. 2011). Consequently, athletic populations tend to possess higher BMD than non-athlete counterparts. Training and competition in weight-bearing sports that comprise high strain rates and peak-force loading characteristics on bone result in enhanced total or sitespecific BMD as shown across a number of sports (Torstveit and Sundgot-Borgen 2005). This principle, however, can be more complex in sports that are associated with low body mass or reduced energy availability, such as endurance running, where low BMD and stress fractures can be observed (Pollock et al. 2010; Loucks 2007). Additionally, the volume of physical activity completed in childhood and the age at which an athlete may have started their sport may also have implications for BMD across the lifespan. Generally, childhood and the pre-pubertal years are considered a key period for bone accretion (Weaver et al. 2016). A large volume of research into the effect of physical activity on BMD and/ or osteoporosis has been completed although limited investigations exist regarding certain athletic populations such as endurance runners. Moreover, many studies have used questionnaires to assess physical activity level, which can lack accuracy or reliability (Prince et al. 2008) and thus, the exact contribution of physical activity remains unclear and requires further exploration across population groups.

A large genetic component to BMD also exists, with heritability of BMD suggested to be $50-85 \%$ depending upon anatomical location (Ralston and Uitterlinden 2010). Knowing the genetic variants associated with BMD could have substantial implications for future research, as well as application and rehabilitation management in both the public health domain and elite sporting environment. For example, accuracy of fracture risk classification was improved by $7-10 \%$ in osteopenic patients by adding an early genetic risk score (Lee et al. 2014) whilst modifying training programmes based on genetic characteristics reduced injury rates in endurance athletes (Goodlin et al. 2015). Practical application using genetics, however, is currently very restricted due to limited evidence on proposed candidate genes associated with BMD. Over 66 genetic loci have been associated with dual-energy X-ray absorptiometry (DXA)-derived BMD or fracture via genome-wide association studies (GWAS) thus far (Hsu and Kiel 2012; Estrada et al. 2012) and this number will continue to increase. Additionally, many of the previously discovered candidate genes have had little or no replication through further study, which means only a very small number can be confidently suggested to have an association with BMD (Hsu and Kiel 2012). The biological function or involvement with bone metabolism of 30 of these has also yet to be elucidated and only seven of the 66 have been associated in candidate gene studies previously or positively replicated afterwards (Hsu and Kiel 2012) although some have received no further study as of yet. Studies so far have only elucidated a fraction of BMD variance and thus, some of the unexplained heritability is likely due to a number of factors such as gene-environment interactions (Ackert-Bicknell and Karasik 2013). This could apply most strongly to certain populations such as athletes, due to the substantial influence of physical activity on BMD and a likely gene-mechanical loading interaction.

The genetic influence on BMD and the relationship with physical activity has not been explored extensively. In vitro studies have shown substantial alteration in gene expression following mechanical loading (Mantila Roosa et al. 2011), whilst a small number of candidate genes have reported physical activity interactions in children (Mitchell et al. 2016). A small number of investigations have also been completed in athletic populations across a number of different bone phenotypes. For example, higher total BMD in weight-bearing athletes than controls was observed in the FF (7.7\%) and Ff (6.9\%) but not ff (1.8\%) genotypes of the vitamin $\mathrm{D}\left(1,25\right.$-dihydroxyvitamin $\left.\mathrm{D}_{3}\right)$ receptor $(V D R)$ FokI rs2228570 polymorphism, whilst lower total BMD was only observed in the FF ( $-4.5 \%)$ genotype when comparing swimmers with a control group (Nakamura et al. 2002b). 
Additionally, variants in the purinergic receptor $\mathrm{P} 2 \mathrm{X} 7$ (P2RX7), human TNF receptor superfamily member $11 \mathrm{a}$ (TNFRSF11A) and sclerostin (SOST) genes have been associated with stress fracture in elite athletes (Varley et al. 2015, 2016, 2017). Substantial further study is needed on candidate genes associated with BMD and other phenotypes such as stress fracture, as well as greater exploration of genes that may interact with physical activity and the implications this would have for BMD and wider application in public health and elite sport.

Therefore, the aims of this narrative review are to (1) provide a critical review of the current literature on the influence of physical activity on BMD, particularly in athletic populations such as endurance runners; (2) provide an overview of genetic associations with BMD and highlight studies that have assessed this association in athletic populations; and (3) explore gene-BMD-physical activity interactions and identify future applications these might have in both the public health domain and elite sporting environment.

\section{Bone mineral density (BMD)}

Peak bone mass is a function of bone size and volumetric BMD (Leonard and Bachrach 2012) and thus, is the amount of bony tissue present following skeletal maturation, which can have a substantial influence on osteoporotic risk in later life (Bonjour et al. 1994). BMD is defined as the ratio of mass to the area or volume of bone, which is known as areal $\left(\mathrm{g} / \mathrm{cm}^{2}\right)$ or volumetric $\left(\mathrm{g} / \mathrm{cm}^{3}\right)$ BMD, depending upon the measurement methodology used (Ott et al. 1997). BMD is considered the primary predictor of osteoporotic fracture, although it is important to note other factors when assessing clinical risk (Cranney et al. 2007). BMD accounts for $60-65 \%$ of the variance in bone strength so other factors such as bone geometry, collagen properties as well as trabecular and cortical microarchitecture are also important determinants of bone strength (Schoenau et al. 2002; Fonseca et al. 2014; Cheung et al. 2016).

Bone mass is regulated by the activity of osteocytes in response to a number of stimuli, such as disuse, matrix damage or hormone deficiency (Atkins and Findlay 2012) and the actions of osteoblasts and osteoclasts, which are important for bone formation and resorption. Disproportionate activity rates of these bone cells, for instance, greater net osteoclastic than osteoblastic activity, can cause bone loss, as observed in ageing (Martin and Sims 2005). Approximately $85-95 \%$ of peak bone mass is attained around late adolescence (Henry et al. 2004; Walsh et al. 2009). After peak bone mass is reached, BMD loss occurs as we age (Fig. 1) and the rate of loss plays an important role in bone health and the development of related conditions, such as osteoporosis (Hernandez et al. 2003). BMD deterioration varies between individuals as well as anatomical sites, with yearly rates of decline after the age of 25 years at the distal radius, distal tibia and lumbar spine reportedly $0.40 \%, 0.24 \%$ and $1.61 \%$, in women and $0.38 \%, 0.40 \%$ and $0.84 \%$, in men. Additionally, men and women experience $42 \%$ and $37 \%$ of trabecular bone loss as well as $15 \%$ and $6 \%$ of cortical bone loss before the age of 50 years (Riggs et al. 2008). Similar to the ability to enhance peak BMD with lifestyle choices, it is possible to slow the inevitable decline in BMD with ageing using preventative measures via lifestyle modification. Some of these factors include not smoking (Law and Hackshaw 1997), maintaining a healthy dietary intake (Darling et al. 2009) and relatively high physical activity level (Pluijm et al. 2001; Krall and Dawson-Hughes 1993).

\section{BMD and physical activity}

Quantifying the relative contributions of physical activity and other determinants to BMD remains difficult. Exercise/ physical activity reportedly accounts for up to $30 \%$ of the variability in total BMD (Table 1), emphasising that the contribution of physical activity to BMD remains unclear and requires further exploration across various population groups.

Initially proposed by Wolff's law and Frost's mechanostat theory, bone adapts or remodels in response to the forces or demands placed upon it (Frost 1990). This mechanotransduction is completed through four steps: mechanocoupling, biochemical coupling, signal transmission and effector cell response (Duncan and Turner 1995). Bone metabolism is regulated via specific pathways, such as the receptor activator of nuclear factor $\mathrm{\kappa B} /$ receptor activator of nuclear factor $\mathrm{kB}$ ligand/osteoprotegerin (RANK/RANKL/OPG), Wnt signalling and purinergic signalling pathways, through initiation of osteoblastic or osteoclastic activity (Tyrovola and Odont 2015). Following physical activity, osteocytes detect shape and volume changes to increase or decrease the liberation of these bone mediators, which consequently influences bone formation and resorption (Nakashima et al. 2011). This notion has been observed in numerous populations including children, adults and older adults, with those who complete a large volume of physical activity/exercise possessing greater BMD, strength and muscle mass (Chilibeck et al. 1995; Slemenda et al. 1991; Beck and Snow 2003; Warburton et al. 2006). The point in time when this physical activity occurs may also influence bone development and bone mass, potentially resulting in lifetime benefits for skeletal health (Gunter et al. 2012). Generally, weight-bearing activity in childhood has been shown to increase total body BMD in adolescents and children (Weeks et al. 2008; Heidemann et al. 2013), as well as demonstrate a continued benefit into adulthood at key sites such as the femoral neck and lumbar spine (Strope et al. 2015). Tveit et al. (2013) reported that exercise-associated 
Fig. 1 Schematic representation of typical age- and sex-related loss of BMD in men and women

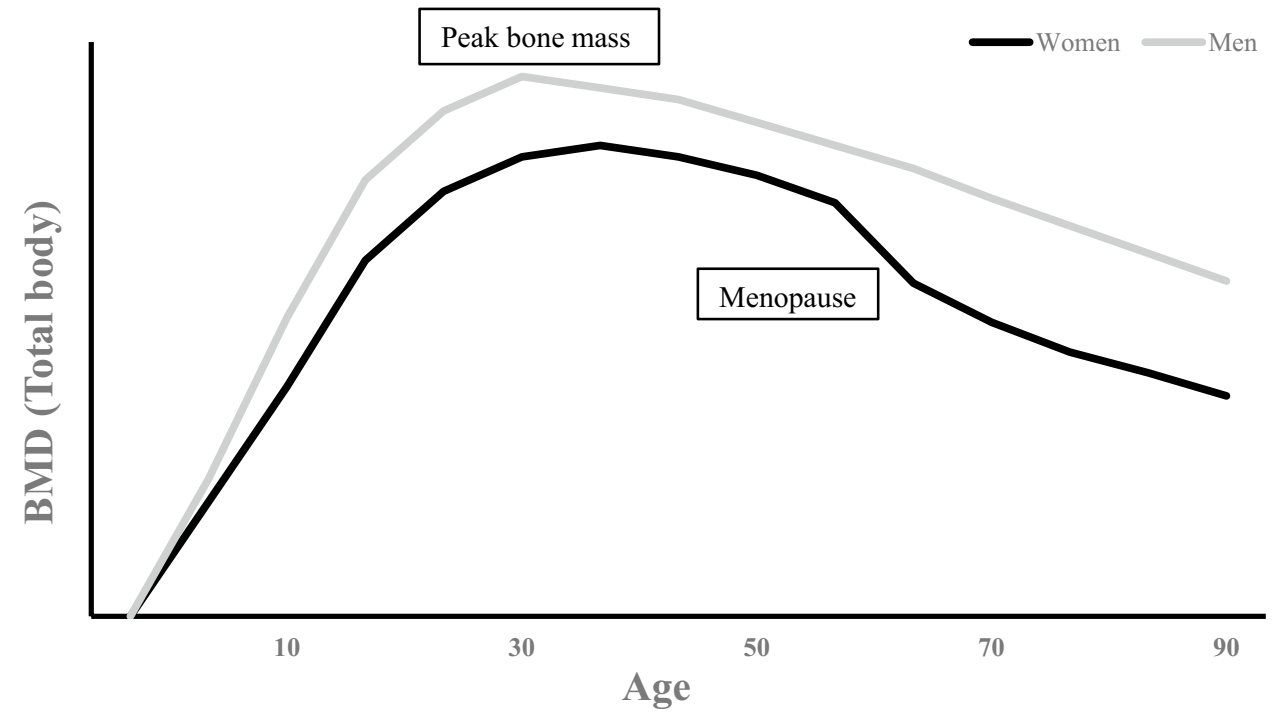

Table 1 Contribution of physical activity to BMD

\begin{tabular}{|c|c|c|c|}
\hline Population & BMD determinant & Variability in BMD & References \\
\hline $\begin{array}{l}\text { Icelandic women } \\
\text { aged } 16-20 \text { years }\end{array}$ & Lean mass and physical exercise & $30 \%$ & Valdimarsson et al. (1999) \\
\hline $\begin{array}{l}\text { Men and women } \\
\text { aged 20-25 years }\end{array}$ & Sports activities & $\begin{array}{l}10.4 \% \text {-men } \\
<1 \% \text {-women }\end{array}$ & Neville et al. (2002) \\
\hline $\begin{array}{l}\text { Pre-menopausal women } \\
\text { aged } 35-37 \text { years }\end{array}$ & $\begin{array}{l}\text { Member of sports club completing } \\
\text { persistent weight-bearing activity } \\
\text { in adulthood }\end{array}$ & $5-19 \%$ & Barnekow-Bergkvist et al. (2006) \\
\hline $\begin{array}{l}\text { European Caucasian men } \\
\text { aged } 65-80 \text { years }\end{array}$ & $\begin{array}{l}\text { High-impact unilateral training } \\
\text { programme on one leg (EL) in } \\
\text { comparison with the other leg } \\
\text { (CL) }\end{array}$ & $\begin{array}{l}1.6 \% \text { net gain in femoral neck } \\
\text { between EL and CL }\end{array}$ & Allison et al. (2015) \\
\hline $\begin{array}{l}\text { Men and women } \\
\text { aged } 20-54 \text { years }\end{array}$ & Physical activity level & $\begin{array}{l}\text { Active women and men had } \\
2.7-4.6 \% \text { and } 1.9-3.0 \% \text { higher } \\
\text { BMD, respectively, than seden- } \\
\text { tary counterparts }\end{array}$ & Morseth et al. (2010) \\
\hline $\begin{array}{l}\text { Men } \\
\text { aged } 17-20 \text { years }\end{array}$ & Physical activity habits & $10.1 \%$ & Pettersson et al. (2010) \\
\hline
\end{tabular}

high $\mathrm{BMD}$ in 46 young male athletes (mean age $=22$ years) was preserved three decades after retirement and cessation of high volumes of physical activity. Similarly, ex-professional baseball players in their ninth decade of life retained more than half of the throwing-related benefits in bone size and a third of the throwing-related benefits in bone strength observed in current professionals (Warden et al. 2014).

Some studies have suggested that activity completed in the pre-pubertal stage is the most favourable to instigate bone development due to the elevated levels of growth hormone present at this time (Bass et al. 1998). Growing bone has an enhanced capability to respond to increased mechanical loading and thus initiate greater structural adaptations to this stimulus, compared to adult bone (Bass et al. 1998). This notion of an optimal period or "window of opportunity" for exercise-induced bone development could be important in improving bone health by maximising peak bone mass attainment during this time (Bass et al. 1998) and therefore, delaying the onset of age- or menopause-related osteoporosis (Santos et al. 2017). Despite this, Behringer et al. (2014) completed a meta-analysis suggesting that weight-bearing activities in childhood and adolescence had no significant influence on BMD in adulthood. The authors based their conclusion, however, on 27 studies out of a possible 109 completed before 2012 and suggest their findings might have been skewed as a result. Therefore, the overall consensus, as outlined by the National Osteoporosis Foundation's recent position statement, is that the best evidence suggests a positive effect of physical activity during late childhood and 
pre-pubertal years and this is a key period for bone accretion (Weaver et al. 2016).

The ability to complete studies that are both longitudinal and valid accounting for accurate measurement of activity (i.e. quantifying intensity in relation to the bone-loading forces experienced) is extremely problematic. Many investigations have used self-report activity questionnaires rather than more direct measurements, such as via accelerometers or pedometers (Ondrak and Morgan 2007). Self-report questionnaires rely upon recall and response bias; correlations between self-report and direct measurement of physical activity have been reported as low-to-moderate, ranging from -0.71 to 0.96 (Prince et al. 2008). Whilst accelerometers are capable of objectively quantifying activity level, this is still an estimation limited by validity, reliability and calibration concerns (Troiano et al. 2014) as well as being unable to provide direct measurement of the stimulus applied to any particular bone or the skeleton as a whole. Furthermore, there has been much methodological variance in studies exploring this topic, such as participant characteristics and sample size, the differing methods used to measure physical activity and types of physical activity/exercise completed in the training intervention. These factors make it difficult to draw conclusions on the exact influence of physical activity on BMD and may explain the large variability in the extent of the skeletal response to loading reported in intervention studies. For reviews on this topic, see Warburton et al. (2006) and Ondrak and Morgan (2007).

Quantifying the optimum amount of physical activity for bone health is both difficult and complex when considering all of the potential confounding variables. Research has suggested that the current US Department of Health and Human Services and UK Chief Medical Office physical activity guidelines do not allow maximisation of BMD potential (Whitfield et al. 2015). Additionally, the type of physical activity may also be important for optimising BMD. Habitual levels of high, but not moderate or light, physical activity was positively related to BMD in adolescents (Deere et al. 2012) as well as in older adults (Hannam et al. 2017). However, high impacts in adolescents were classed as $>4.0 \mathrm{~g}$ but only $>1.5 \mathrm{~g}$ in the older adults. Thus, the impact threshold required to combat bone loss is likely to be lower in older adults but higher $g$ forces may be required to stimulate acquisition during peak attainment in childhood (Tobias 2014), which adds further complexities to understanding the influence of physical activity on bone health. Therefore, due to the difficulty of quantifying physical activity and the large number of determinants of BMD, investigating the influence or association of physical activity on BMD is challenging. Using homogenous cohorts that are known to be undertaking similar amounts of physical activity, such as athletic populations, can somewhat alleviate this issue.

\section{BMD in athletic populations}

Physical activity can be defined as any movement implemented by skeletal muscle that results in energy expenditure, whereas exercise refers to physical activity that is planned, structured and repetitive with an aim to maintain or improve a physical fitness component (Caspersen et al. 1985). Therefore, athletic populations who complete large volumes of exercise also tend to possess higher BMD and bone mass than non-athletic individuals via the loading adaptation mechanisms mentioned above (Chilibeck et al. 1995). However, the loading characteristics of different sports vary, thus the BMD of athletes partaking different sports or disciplines also varies, particularly between different anatomical sites (Mudd et al. 2007; Bennell et al. 1997). One of the earliest applied studies investigating BMD of athletes competing in different sports showed significantly higher total and site-specific BMD in volleyball players in comparison with gymnasts, swimmers and non-athletic controls, although the BMD of the gymnasts was significantly higher than the other two groups (Fehling et al. 1995). This emphasises that physical activity/exercise, which expresses higher impacts through increased strain rates and high peak-force loading characteristics, as can be expected of volleyball players, results in enhanced total or site-specific BMD as shown across of a number of sports (Table 2).

In endurance runners specifically, most studies have shown a higher BMD than control populations, particularly at the primary loading sites (tibia, femoral neck, calcaneus), although this is not always the case due to other variables, such as low energy availability (Scofield and Hecht 2012). However, endurance runners tend to have lower BMD than athletes from other weight-bearing sports, such as sprinters or gymnasts, where forces applied to bone are more likely to be varied in magnitude and directions (Scofield and Hecht 2012). Master athletes over the age of 65 years who are still competing in running events have been shown to possess higher BMD than non-active counterparts (Velez et al. 2008). Furthermore, former elite runners, soccer players and weightlifters have been shown to possess higher BMD than non-active controls as well as suffer osteoporotic hip fractures at a significantly older age (Kettunen et al. 2010). This emphasises the potential of BMD to be maintained and the importance of weight-bearing exercise in contributing to skeletal integrity in later life.

Studying athletes who experience extreme amounts of loading can somewhat compensate for the aforementioned limitations associated with quantifying physical activity. Elite athletes in weight-bearing sports are a unique population who generally experience extreme amounts of mechanical loading, which, although not a perfect solution, presents an attractive model for future research studies hoping to 
Table 2 BMD variation across different sports

\begin{tabular}{|c|c|c|c|}
\hline Population & Sport & $\mathrm{BMD}$ variation & References \\
\hline $\begin{array}{l}300 \text { Norwegian female elite athletes } \\
\text { (national level at senior or junior) } \\
300 \text { non-athletic controls }\end{array}$ & 66 sports & $\begin{array}{l}3-20 \% \text { higher BMD than controls. } 3-22 \% \text { higher BMD } \\
\text { in high-impact sports compared to medium- or low- } \\
\text { impact sports }\end{array}$ & $\begin{array}{l}\text { Torstveit and Sund- } \\
\text { got-Borgen (2005) }\end{array}$ \\
\hline $\begin{array}{l}15 \text { elite male athletes } \\
15 \text { non-athletic controls }\end{array}$ & Volleyball & $\begin{array}{l}14 \% \text { and } 24 \% \text { higher BMD at the lumbar spine and } \\
\text { femoral neck, respectively, in volleyball players in } \\
\text { comparison with non-athletic controls }\end{array}$ & Calbet et al. (1999) \\
\hline $\begin{array}{l}14 \text { state-level female athletes } \\
18 \text { non-athletic controls }\end{array}$ & Netball & $\begin{array}{l}7.8 \%, 17.3 \% \text { and } 14 \% \text { higher total body, hip and lumbar } \\
\text { spine BMD in the netballers in comparison with the } \\
\text { controls }\end{array}$ & Chang et al. (2013) \\
\hline $\begin{array}{l}50 \text { male highly trained athletes } \\
12 \text { non-athletic controls }\end{array}$ & $\begin{array}{l}12 \text { judokas } \\
14 \text { karate athletes } \\
24 \text { water polo players }\end{array}$ & $\begin{array}{l}\text { Control group total body BMD }\left(1.27 \mathrm{~g} / \mathrm{cm}^{2}\right) \text { was sig- } \\
\text { nificantly lower than the judo }\left(1.40 \mathrm{~g} / \mathrm{cm}^{2}\right) \text { and karate } \\
\left(1.36 \mathrm{~g} / \mathrm{cm}^{2}\right) \text { group but no different to the water polo } \\
\text { athletes }\left(1.31 \mathrm{~g} / \mathrm{cm}^{2}\right)\end{array}$ & Andreoli et al. (2001) \\
\hline $\begin{array}{l}59 \text { competitive Finnish female athletes } \\
25 \text { physical active individuals } \\
25 \text { sedentary individuals }\end{array}$ & $\begin{array}{l}27 \text { dancers } \\
18 \text { squash players } \\
14 \text { speed skaters }\end{array}$ & $\begin{array}{l}\text { Squash players had significantly higher BMD at the } \\
\text { lumbar spine (13\%), femoral neck }(16.8 \%) \text {, proximal } \\
\text { tibia }(12.6 \%) \text { and calcaneus }(18.5 \%) \text { in comparison } \\
\text { with the sedentary group. Aerobic dancers also had } \\
\text { significantly higher BMD at the loaded sites in com- } \\
\text { parison with the sedentary group, ranging from } 5.3 \text { to } \\
13.5 \%\end{array}$ & Heinonen et al. (1995) \\
\hline $\begin{array}{l}60 \text { athletes } \\
15 \text { non-athletic controls }\end{array}$ & $\begin{array}{l}15 \text { runners } \\
15 \text { swimmers } \\
15 \text { triathletes } \\
15 \text { cyclists }\end{array}$ & $\begin{array}{l}\text { Runners had significantly higher total body, femoral } \\
\text { neck and leg BMD than controls and swimmers as } \\
\text { well as higher leg BMD than cyclists }\end{array}$ & Duncan et al. (2002) \\
\hline
\end{tabular}

investigate the impact of exercise on BMD. Additionally, by selecting homogeneous athlete groups, who compete in the same event to a similar standard, it would be reasonable to assume these individuals undertake similar training regimes/ volumes. For instance, Billat et al. (2001) reported highlevel male marathon runners with a personal best of $<2 \mathrm{~h}$ $16 \mathrm{~min}$ ran an average weekly distance of $168 \mathrm{~km}( \pm 20 \mathrm{~km})$ and females with a personal best of $<2 \mathrm{~h} 36 \mathrm{~min}$ completed $150 \mathrm{~km}( \pm 17 \mathrm{~km})$ on average.

\section{BMD, elite athletes and injury risk}

Despite the benefits of weight-bearing activity for BMD, at the elite sporting level, too much activity to the point of overtraining can result in negative outcomes (Kuipers and Keizer 1988). A stress fracture would be one such outcome and is defined as a partial or complete fracture of bone from repeated application of force lower than that required to fracture a bone in a single loading (Iwamoto and Takeda 2003). Stress fracture injury occurs due to the repetitive mechanical loading that stimulates an incomplete remodelling response (Jones et al. 2002) and several factors are known to influence an individual's susceptibility to experience a stress fracture (Bennell et al. 1999). Such factors include biomechanical gait (Milner et al. 2006), bone size and mechanical properties (Tommasini et al. 2005), nutritional factors (Nieves et al. 2010), training volume and rapid increments in volume
(Snyder et al. 2006), small musculature and low BMD (Beck et al. 2000).

Unsurprisingly, higher incidence of lower limb stress fractures is observed in endurance runners in comparison with non-athletic controls. Significant amounts of site-specific loading combined with other factors typical of this group, such as low energy availability, can result in lower BMD and a higher risk of fracture occurrence (Loucks 2007). Stress fractures reportedly account for $50 \%$ of all injuries sustained by runners and military recruits, with higher incidence observed in females (Milner et al. 2006). However, there is a lack of research on stress fractures in running populations (Wright et al. 2015). Although lower BMD has been observed at the foot in female athletes with a history of stress fracture, compared to those without, this was accompanied by lower lean mass, leg-length discrepancy and fewer menstrual cycles per year, which may be influential (Bennell et al. 1996). Furthermore, determining accurate prevalence is also difficult due to the problematic nature of defining stress fractures. Significant misdiagnosis will occur unless limited to radiography, although this can still lack sensitivity and specificity (Wright et al. 2016).

Investigating BMD, with a particular emphasis on injury, is undoubtedly important because stress fractures have substantial implications for athletes. For instance, Marathon world record holder, Paula Radcliffe, reportedly suffered a stress fracture 3 months before the 
Beijing 2008 Olympics, limiting her preparation for and performance at that competition. Furthermore, Ranson et al. (2010) reported $43 \%$ of the elite fast bowlers they investigated developed symptomatic acute lumbar stress fractures in a 2-year follow-up period and subsequently missed 169 days of cricket, per episode, on average.

If athletes are unable to complete their desired or required training volume due to injury, this could have substantial negative effects on their performance and success. Additionally, if an athlete knows they may be susceptible to injury, this could be accounted for in their training programmes, by placing a greater emphasis on appropriate strengthening exercises and/or allowing longer rest periods between sessions. This valuable information for tailored training could then ultimately influence progression of athletes from amateur to elite or have implications for selection into high-level teams or sporting competitions. It is apparent that a substantial proportion of research in this area has been completed in military recruits (Wright et al. 2015). This is probably due to the ease of accessing large samples who undertake a quantifiable training load, as well as a desire to minimise waste of human and financial resources caused by injuries. However, it is difficult to directly extrapolate the findings of these military studies to elite runners due to differences in the level of physical fitness, footwear and the loads carried whilst running between these groups. Despite possible stress fractures, the positive benefits of physical activity/exercise on BMD in a broad population are evident. As discussed, there are a number of determinants influencing BMD but relatively little is known about the genetic influence on this phenotype and stress fractures, which could be pivotal for future understanding in both the sporting and public health domains.

\section{Genetic association with BMD}

Although BMD is a multi-factorial phenotype, heritability of BMD is suggested to be $50-85 \%$ depending upon anatomical location (Ralston and Uitterlinden 2010). However, it must be emphasised that this proposed large genetic component is in a free-living population where most people will not complete extreme volumes of physical activity or be severely malnourished and thus, the influence of these other environmental factors on BMD will be reduced. Therefore, even a very substantial genetic contribution to BMD does not mean physical activity or other factors cannot notably affect an individual's BMD (as shown in "BMD and physical activity").

Due to this substantial genetic component, knowing the associated variants could be extremely beneficial for both functional research focus as well as application.
For example, accuracy of fracture risk classification was improved by $7-10 \%$ at various sites in osteopenic patients by adding a genetic risk score from proposed common or rare variants associated with $\mathrm{BMD}$ and/or osteoporosis (Lee et al. 2014). In the future, this application might be utilised in athletic populations for risk stratification and injury prevention. However, utilising a genetic risk score with elite athletes is currently difficult due to a lack of known candidate genes associated with BMD in athletic populations, which emphasises the need for replication of potential candidate genes and specific studies on particular populations, who may possess high or low BMD, or demonstrate specific lifestyle choices/habits that influence BMD.

Beginning in clinical populations, studies that selected candidate genes for association with BMD due to known biological function, such as $V D R$, insulin-like growth factor $1(I G F 1)$ and oestrogen receptor 1 (ESRl) (Gong and Haynatzki 2003), produced inconclusive findings. Candidate gene selection can be based on the premise that the protein plays a role in regulating bone cell function or calcium metabolism (Ralston and de Crombrugghe 2006), and the differing variants may affect bone mediators and consequently influence BMD. For example (as highlighted in Fig. 2 below), the human TNF receptor superfamily member $11 \mathrm{~b}$ (TNFRSF11B) gene encodes the protein osteoprotegerin (OPG), which regulates bone resorption by inhibiting differentiation and activation of osteoclasts. OPG-deficient mice have been found to develop early-onset osteoporosis, and increased tissue mRNA expression has been observed in participants who possess specific haplotypes accompanied with reduced BMD, which may be due to increased expression resulting in stimulated osteoclast activity (Takács et al. 2010). This simplistic model forms the basis of genetic regulation on BMD but, in reality, the process is much more complex due to environmental factors and various kinds of interactions, which could have a substantial effect on gene expression and phenotype outcome. This potential impact of mechanical loading on gene expression can be understood by the substantial upregulation and downregulation of numerous genes following mechanical loading in rats (Mantila Roosa et al. 2011). Genes including FOS-like 1, AP-1 transcription factor subunit (FOSL1) and JunB protooncogene, AP-1 transcription factor subunit $(J U N B)$ were both upregulated within $4 \mathrm{~h}$ after loading, whilst expression of Wnt/ $\beta$-catenin signaling genes SOST and secreted frizzled-related protein 4 (SFRP4) was also altered in the synthetic phase of bone formation (Mantila Roosa et al. 2011). In the case of OPG, in vitro evidence demonstrated that compressive forces increase IL- 6 and $\mathrm{PGE}_{2}$ production through the activation of intracellular calcium/extracellular signal-regulated kinase $1 / 2$ and nuclear factor- $\mathrm{\kappa B}$ 
Fig. 2 TNFRSF $11 B$ genotype influence on OPG availability and subsequent bone formation with the potential of environmental and interaction effects

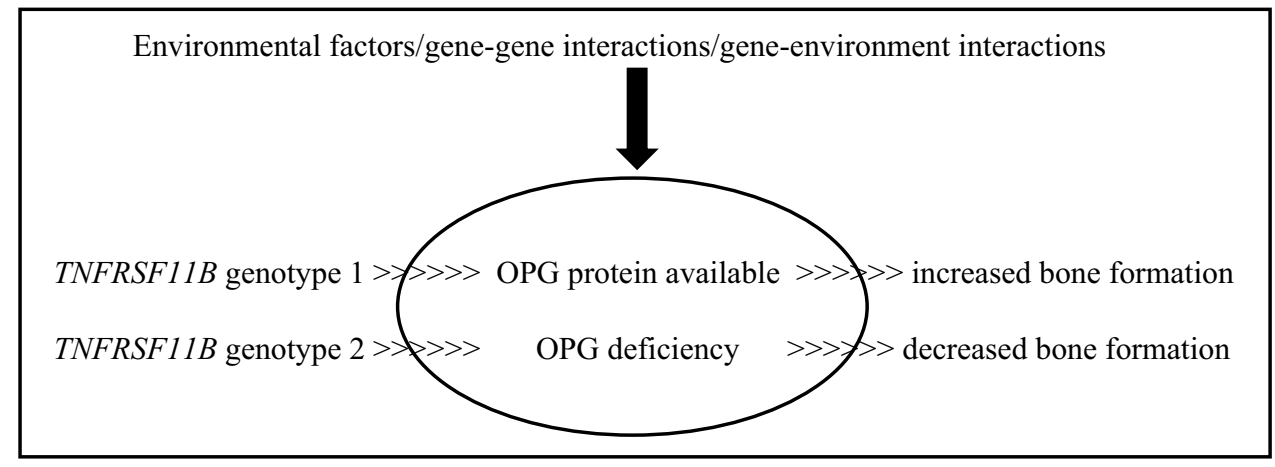

translocation $(\mathrm{Ca}++/ \mathrm{ERK} 1 / 2 / \mathrm{NF}-\kappa \mathrm{B})$ signalling pathways, which results in decreased osteoblast OPG expression (and a decreased OPG/RANKL ratio) and enhanced matrix metallopeptidase (MMP) production, consequently increasing bone resorption (Sanchez et al. 2009).

Recent technological advances and large collaborations have seen a number of genome-wide association studies (GWAS) with BMD completed, which identified many more potential candidate genes and SNPs (Richards et al. 2012; Clark and Duncan 2015). However, the most prominent study to date, a meta-analysis conducted by Estrada et al. (2012), identified 56 loci associated with BMD, osteoporosis and/or fracture that accounted for $\sim 6 \%$ of the variation in BMD. Overall, more than 66 genetic loci have been associated with (DXA derived) BMD via GWAS method, as well as many others through candidate gene association studies, and this number continues to increase, emphasising the extremely polygenic nature of BMD (Golchin et al. 2016). A further 153 loci have been associated with BMD estimated by quantitative ultrasound of the heel (Kemp et al. 2017). A specific recent addition, for instance, is a locus harbouring the Patched 1 (PTCH1) gene in an Icelandic population (Styrkarsdottir et al. 2016). This rapid discovery rate of new candidate genes and the fact many previously discovered candidate genes have had little or no replication through further study means only a very small number can be confidently suggested to have an association with BMD. Furthermore, the biological function or involvement with bone metabolism of 30 of these has yet to be elucidated and only 7 of the 66 have been associated in candidate gene studies previously or positively replicated afterwards (Hsu and Kiel 2012) although some have received no further study as of yet. To have only seven candidate genes positively associated through both methods so far is surprising, considering almost 100 different loci have been associated with BMD via a candidate gene approach (Hsu and Kiel 2012). Hsu and Kiel (2012) suggested a number of reasons why this may have occurred; first, false-negative findings due to the stringent level of statistical significance typically applied to GWAS data, or inadequate statistical power in some studies that were unable to replicate associations with modest effect sizes. On the other hand, false-positive findings of candidate gene association studies may have prevailed due to small sample sizes or publication bias (Munafo et al. 2004).

Additionally, strong gene-gene or gene-environment interactions could alter the number and identity of loci associated with BMD. This could apply to specific populations, such as athletes, due to the substantial influence of physical activity on BMD. Ultimately, this has resulted in few candidate genes emerging from GWAS and/or association studies that also have a known biological function relevant to bone. Therefore, further research using well-defined independent cohorts is needed to provide further evidence (Agueda et al. 2010). Clark and Duncan (2015) suggest greater use of "extreme cohorts" who might possess variants that have stronger associations with relevant phenotypes, which could include elite athletes at one end of a continuum (as mentioned in "BMD in athletic populations") and osteoporotic individuals at the other. This approach has been applied to BMD successfully in a study of postmenopausal women with extremely high or low BMD, where GWAS revealed six novel genetic associations (Duncan et al. 2011).

Studies so far have only elucidated a small fraction of BMD variance and thus some of the unexplained heritability is likely due to a number of factors, including gene-environment interactions (Ackert-Bicknell and Karasik 2013). Despite the substantial effect of physical activity/exercise on $\mathrm{BMD}$, there has been little research regarding gene-physical activity interactions and its effects on BMD in athletic populations. Therefore, this limited amount of research, as well as the variance in sample size and participant characteristics, means it is difficult to evaluate the extent of the gene-physical activity interaction with BMD or propose any definitive candidate genes that interact with environmental factors in determining BMD. However, looking at this relationship using specific cohorts or populations is gathering momentum-for example, investigations exploring interactions with others phenotypes, including obesity, are now being conducted (Marti et al. 2008). As mentioned previously ("BMD in athletic populations"), athletes would 
be an excellent sample group to explore this interaction as they present an extreme cohort regarding exercise undertaken and BMD.

\section{Genetic association with BMD and the relationship with physical activity}

Mitchell et al. (2016) were the first to investigate the genetic influence on BMD and the relationship with physical activity using SNPs that had been associated with BMD using GWAS (Estrada et al. 2012). Analysis revealed physical activity interacted with ELKS/Rab6-interacting/CAST family member $1 /$ Wnt family member $5 \mathrm{~B}$ (ERC1/WNT5B) rs2887571 to influence bone mineral content in males and nominal interactions with physical activity were also observed with Wnt family member 16 (WNT16) rs3801387, axin 1 (AXINI) rs9921222, SOST rs4792909 and stARrelated lipid transfer domain containing $3 \mathrm{~N}$-terminal-like (STARD3NL) rs6959212. Sclerostin has a negative effect on bone formation by inhibiting canonical Wnt signalling in osteoblasts and also stimulates osteoclastic bone resorption by increasing the RANKL/OPG ratio (via enhanced RANKL expression) (Appelman-Dijkstra and Papapoulos 2016). Despite this strong influence on bone metabolism, conflicting results regarding SOST variants and association with BMD have been reported in the literature (Sharma et al. 2015). Additionally, serum sclerostin concentration has been positively correlated with lumbar spine, femoral neck and total hip BMD but no variants were associated with BMD or sclerostin concentration (He et al. 2014). It is important to note that children/young adults (age 5-19 years) were the investigated cohort in the Mitchell et al. (2016) study. It is suggested that some BMD-associated loci may exert agespecific effects (Medina-Gomez et al. 2012), and thus the findings cannot be generalised to other populations.

Interesting findings have also been reported in candidate gene association studies. Kiel et al. (2007) discovered two SNPs in the LDL receptor-related protein 5 (LRP5) gene associated with differences in BMD, which were dependent upon volume of physical activity completed. The TT genotype of both the rs3736228 and rs2396862 SNPs was associated with lower BMD in more physically active men, but with higher BMD in less physically active men. Thus, the authors hypothesised that the substitution of a $\mathrm{C}$ with a $\mathrm{T}$ allele in the rs3736228 SNP could alter LRP5-mediated Wnt signalling in the case that the catabolic signals induced from the mechanical loading prevail over anabolic signalling. This was also the case when expressing alleles as a haplotype in vitro, where the $\mathrm{T}$ allele was associated with a decreased response to canonical Wnt3a signalling in comparison to the $\mathrm{C}$ allele. Activation of $\mathrm{Wnt} / \beta$-catenin (canonical) signaling increases the sensitivity of osteoblasts to mechanical loading, which can occur via Wnt binding to low-density lipoprotein receptor-related proteins 5 and 6 coreceptors (Robinson et al. 2006; Krishnan et al. 2006). This mediation of Wnt signaling via different $L R P 5$ variants can both enhance and decrease BMD (Ferrari et al. 2005). Lossof-function mutations in $L R P 5$ are also responsible for low bone mass disorders, such as osteoporosis pseudoglioma, whereas gain-of-function mutations have been suggested to cause high bone mass syndromes (Levasseur et al. 2005). Furthermore, LRP5 variants, such as C135242T, have been associated with BMD variability in the general population (Koay et al. 2004) and ds2306862 in osteoporotic individuals (Mizuguchi et al. 2004), which highlights the strong influence LRP5 may have on bone metabolism, particularly when considering a mechanical loading interaction.

Similar to some LRP5 variants, the catechol-O-methyltransferase (COMT) val158met (rs4680) SNP has been reported to influence the association between physical activity and BMD suggesting that certain variants may be particularly important for BMD in individuals with low physical activity levels. Higher total BMD was observed in individuals completing greater levels of physical activity $(>4 \mathrm{~h})$ compared to those undertaking lower activity $(<4 \mathrm{~h})$ for GA and AA (lower enzyme activity) but not GG (higher enzyme activity) genotypes (Lorentzon et al. 2007). Although lower BMD was observed in the lower enzyme activity group, estradiol serum levels were not. COMT catalyses the methylation of catechol oestrogens to methoxy oestrogens (inactive metabolites) and thus lower COMT enzyme activity should result in less efficient inactivation of catechol oestrogens and higher BMD in these genotypes as has been shown in other studies (Eriksson et al. 2005). Therefore, a COMT genotype interaction may be present and the potential regulation of the BMD response to mechanical loading may be due to the involvement of oestrogen receptors as facilitators in a number of key pathways by which mechanical strain stimulates bone formation (Galea et al. 2013).

Interleukin 6 (ILO) is another potential candidate gene with a number of functional polymorphisms, suggested as candidates associated with BMD and/or osteoporosis. Meta-analysis revealed an association between the GG genotype in the $I L 6-174 \mathrm{G} / \mathrm{C}$ (rs1800795) polymorphism and low BMD, as well as increased risk of osteoporosis, in a Caucasian population (Ni et al. 2014). In the $-634 \mathrm{C} / \mathrm{G}$ (rs1800796) polymorphism, the CC genotype was associated with greater BMD in Chinese pre-menarche girls who completed higher levels of physical activity (Li et al. 2008). Similarly, total body, lumbar spine and femoral neck BMD were lower in the GG genotype compared to the $\mathrm{CC}$ genotype by $0.03,0.03$ and $0.01 \mathrm{~g} / \mathrm{cm}^{2}$, respectively, in an Asian population $(n=3068)$ following meta-analysis (Yan et al. 2015). IL-6 is primarily sourced in osteoblastic cells and increases interactions between osteoblasts and osteoclasts, thus stimulating bone resorption (Steeve et al. 2004). IL-6 
is suggested to indirectly stimulate osteoclastogenesis by increasing RANKL gene expression in osteoblasts (Bakker and Jaspers 2015) and the $\mathrm{G}$ allele has been associated with elevated production and secretion of IL-6 in vitro (Kitamura et al. 2002). Therefore, the G allele and thus elevated IL-6 may be disadvantageous for bone density. Although there are limitations regarding control of other BMD-influencing variables and various cohorts used in these studies, IL6 remains interesting, particularly when analysing a possible relationship with physical activity. In vitro studies have suggested IL-6 is produced by shear-loaded osteocytes and may influence bone mass by osteocytes reducing osteoblast activity via IL-6-mediated intercellular signalling (Bakker et al. 2014). Elevated IL-6 serum concentrations have also been observed in trained marathon runners immediately post-race, with a positive correlation between IL- 6 concentration and running intensity (Ostrowski et al. 2000). In longitudinal studies, serum IL-6 concentration has been negatively associated with bone resorption and BMD in older adults although the literature is somewhat conflicting (Ding et al. 2008). IL6 demonstrates the possibility of strong gene-environment interactions and studies that do not control for physical activity risk erroneous findings and/or results that are only applicable to limited portions of the population.

Overall, completing weight-bearing physical activity has been shown to increase BMD as discussed in "BMD and physical activity". The effect of potential gene-physical activity interactions on BMD across the lifespan, however, has yet to be determined. It could be hypothesised that if an individual has a disadvantageous genetic profile and completes low levels of weight-bearing physical activity, they may be at risk for low BMD and potentially osteoporosis in later life (Disadvantageous TGS and low levels of PA) (Figs. 3 and 4). Those who may have a disadvantageous
Fig. 3 Schematic representation of typical age- and sex-related effect of physical activity and genetics loss of BMD in men and the

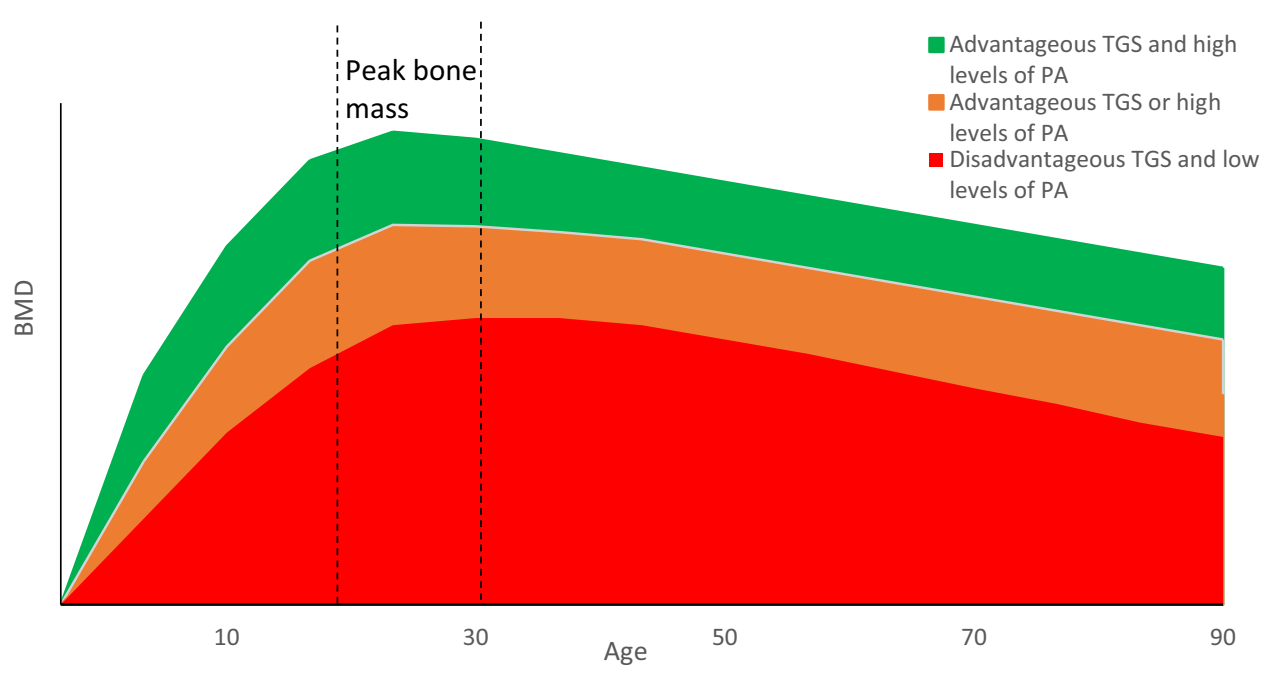

Fig. 4 Schematic representation of typical age- and sex-related loss of BMD in women and the effect of physical activity and genetics

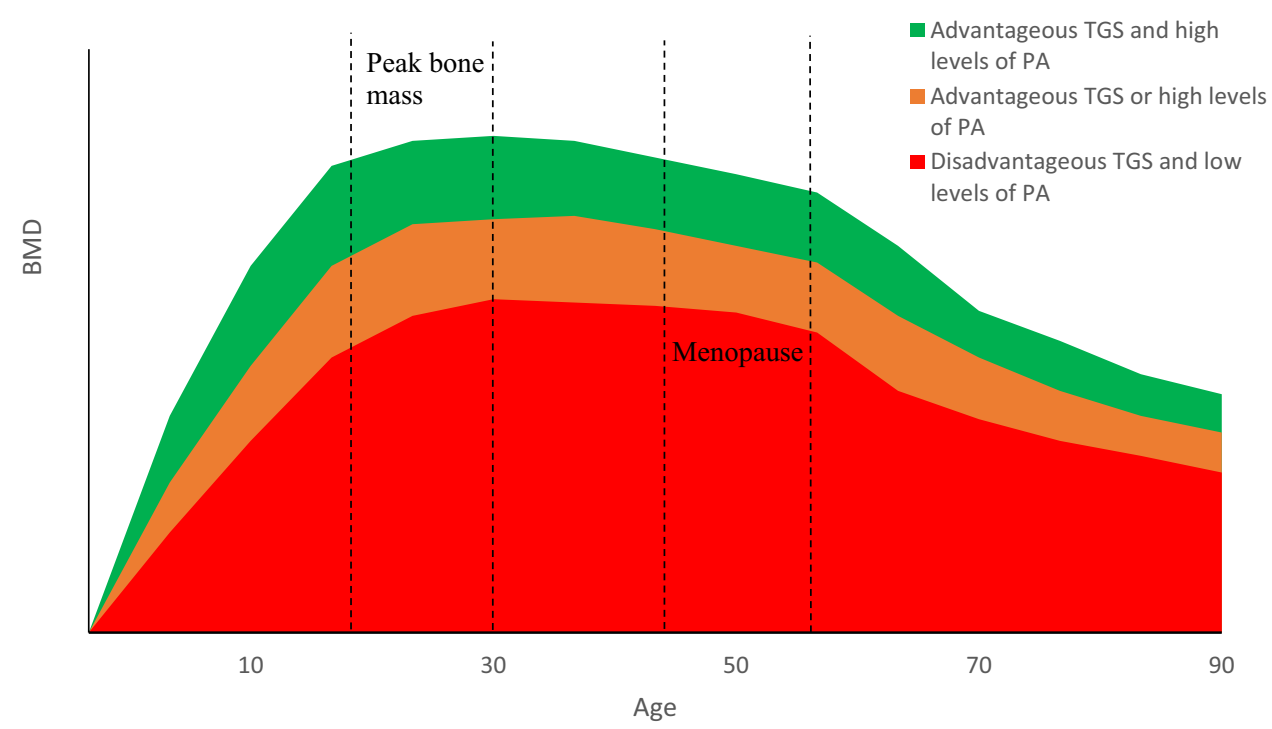


Fig. 5 Schematic hypothetical representation of the BMD outcome for different individuals representing variable genetic profiles (TGS) and levels of physical activity

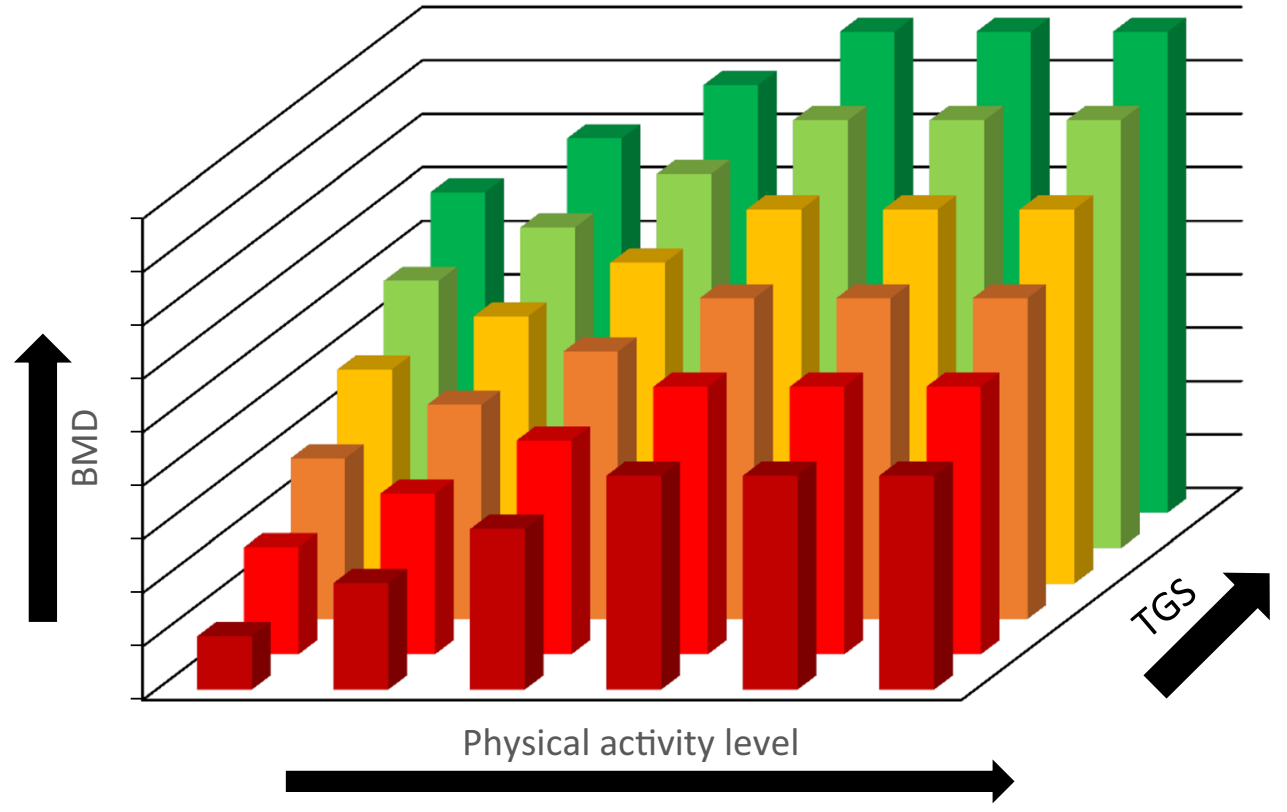

genetic predisposition, however, but complete sufficient weight-bearing activity to produce a substantial osteogenic response may be able to combat their negative genetic predisposition resulting in increased BMD, as evidenced in children (Mitchell et al. 2016) (Advantageous TGS or high levels of PA). Similarly, those who do not complete suitable levels of activity but possess an advantageous genetic profile may also present with moderate BMD (Advantageous TGS or high levels of PA). Those with an advantageous genetic profile who also complete large volumes of weight-bearing physical activity are likely to have the highest BMD (Advantageous TGS and high levels of PA), which could be induced from a gene-physical activity interaction.

In the case of a gene-physical activity interaction, a hypothetical relationship between genetics, physical activity and the resultant BMD is presented below (Fig. 5). Each bar represents a different individual and a hypothetical scenario for BMD ranging from a low BMD to a high BMD (the bar colour indicates BMD at any given level of physical activity in Figs. 5, 6). BMD is dependent on both genetics and physical activity level, so as physical activity level increases, BMD is enhanced for every individual regardless of their BMD before this increase in physical activity occurred. The magnitude of increase in BMD and maximum BMD level attained, however, are under the influence of genetics (Ralston and Uitterlinden 2010). Consequently, those with a more advantageous genetic predisposition, indicated by a higher total genotype score (TGS), combined with a higher volume of mechanical loading are more likely to reach a higher BMD than those with a disadvantageous genetic predisposition and/or a lower volume of mechanical loading, assuming all else is equal.
It is possible, however, that a linear relationship between physical activity dose and BMD response does not exist at the extremes of physical activity (PA). National Health and Nutrition Examination Survey (NHANES) data have previously demonstrated that BMD did not differ between males who reported completing four-six times more physical activity than the recommended guidelines (Whitfield et al. 2015). The physical activity and BMD relationship is still poorly understood and in the case of endurance runners, overtraining can negatively affect BMD (Fig. 6) due to the associated influence of energy availability. Other factors such as the type of activity and dietary intake, however, are also important in regard to the bone adaptation as discussed in "BMD in athletic populations" and would consequently affect this relationship.

\section{Genetic association with BMD in athletic populations}

In 212 young males, significantly higher total body BMD in 84 weight-bearing athletes than 80 controls was observed in the FF (7.7\%) and Ff (6.9\%) but not ff (1.8\%) genotypes of the VDR FokI rs2228570 polymorphism, whilst significantly lower total BMD was only observed in the FF $(-4.5 \%)$ genotype when comparing 48 swimmers with a control group (Nakamura et al. 2002b). This suggests that individuals with the FF genotype may be more responsive to mechanical loading, resulting in greater BMD when that environmental factor is prominent. This notion was further reinforced in 44 Japanese track and field athletes, where higher bone volume was expressed in those with the FF genotype, but not in those with the Ff genotype (Nakamura et al. 2002a). 
Fig. 6 Schematic hypothetical representation of the BMD outcome for different individuals (e.g. endurance runners) representing variable genetic profiles (TGS) and levels of physical activity

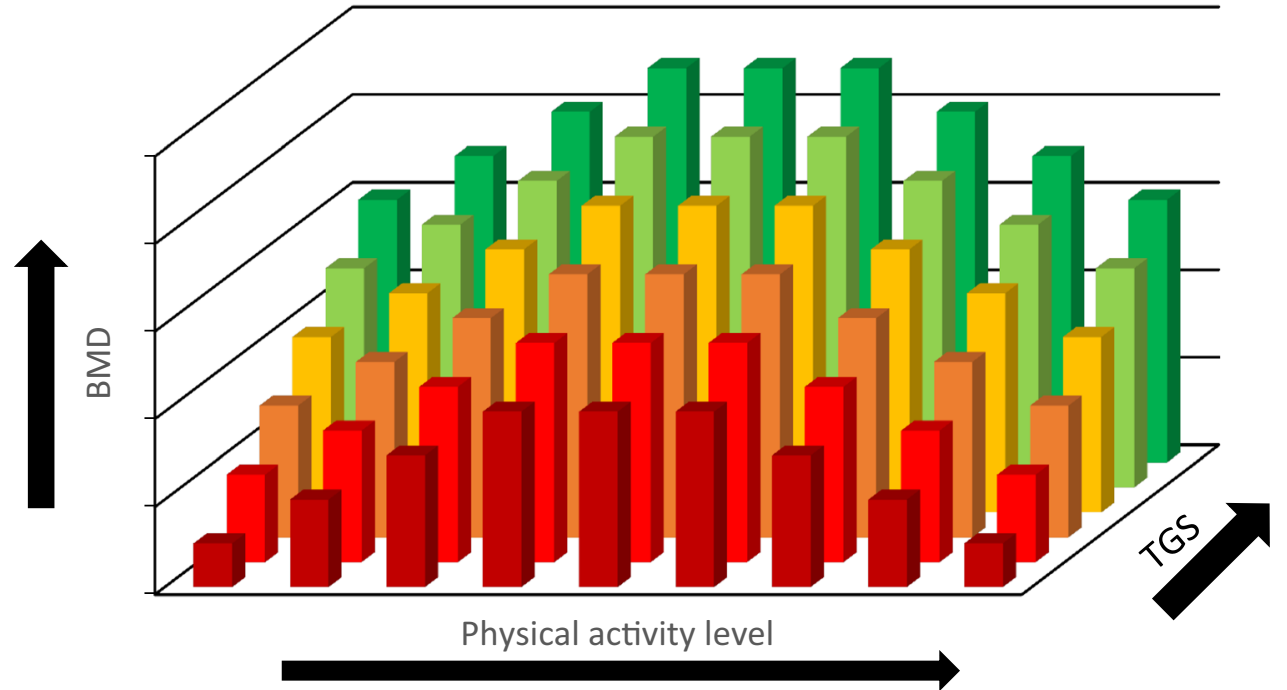

This particular polymorphism, Fokl (rs2228570), exhibits a $\mathrm{C}$ to $\mathrm{T}$ transition that creates an upstream initiation codon, leading to the production of VDR proteins that are three more amino acids in length. The $\mathrm{F}$ allele codes for the absence of the restriction, whilst the f allele codes for the presence of the initiation codon, which leads to the longer amino acid length (Gross et al. 1996; Ames et al. 1999). It is suggested that the $\mathrm{F}$ variant shows greater transactivation (protein expression) than the f variant and this increased biological activity (and associated increased intestinal absorption of calcium) could explain why higher BMD has been reported in those with the FF genotype (Arai et al. 1997; Colin et al. 2000; Uitterlinden et al. 2004; Ames et al. 1999) as detailed below (Fig. 7). VDR controls the transcription of other genes including bone gamma-carboxyglutamate protein/osteocalcin $(B G L A P)$ that are instrumental for this calcium absorption and bone formation (Moran et al. 2014). A direct effect of osteoblastic/osteocytic VDR signalling on bone remodelling has also been proposed, although specific understanding of this notion is still lacking and largely depends on calcium balance (Lieben and Carmeliet 2013).

The potential association of VDR with BMD and/or fracture has also been supported across a number of different SNPs (rs1544410, rs7975232 and rs731236) in various cohorts, such as pre- and postmenopausal women (Riggs et al. 1995; Horst-Sikorska et al. 2007; Ji et al. 2010; Marozik et al. 2013). However, contradictory results have also been reported across these cohorts (Horst-Sikorska et al. 2013; Moran et al. 2015; Castelán-Martínez et al. 2015; Dabirnia et al. 2016). The highly conflicting nature of the findings may be due to not adjusting for covariates (e.g.

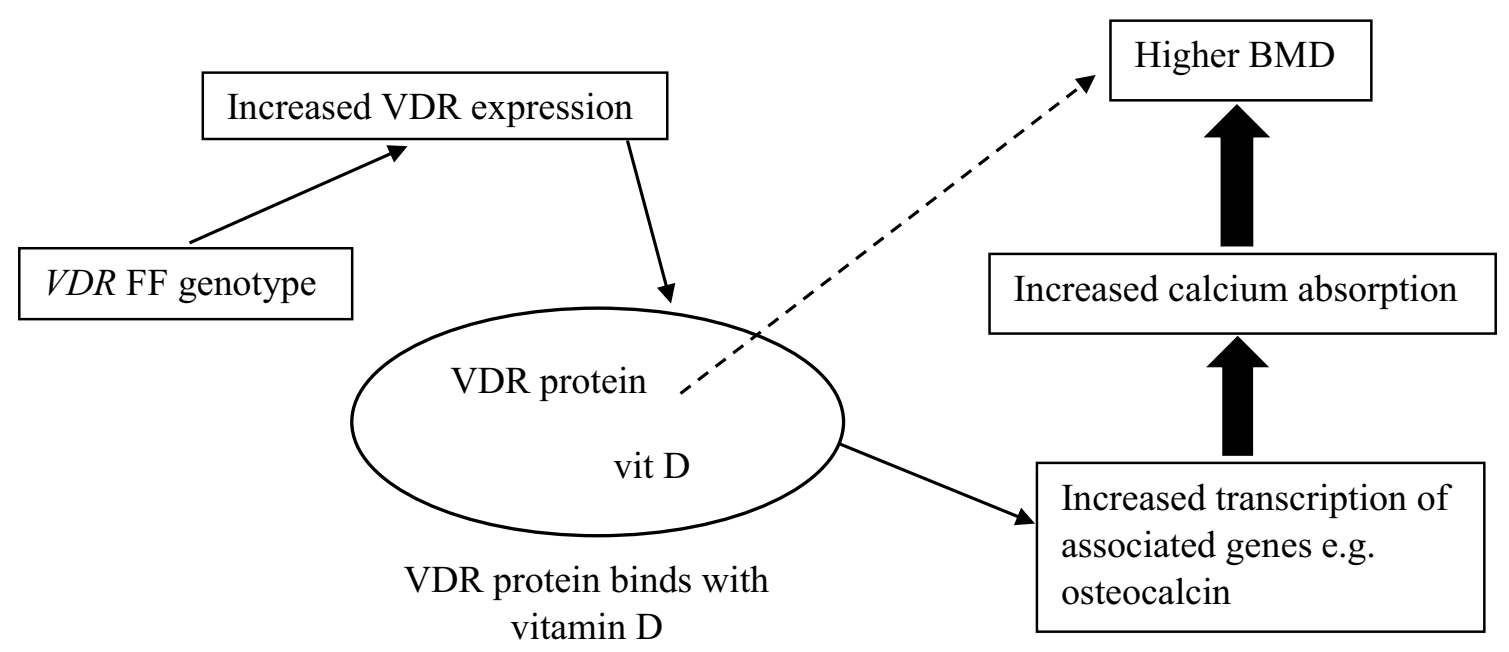

Fig. 7 VDR rs2228570 FF genotype and the associated pathways leading to enhanced BMD 
BMI) as well as the different ethnic groups, sample sizes and study designs utilised (Xu et al. 2005).

A recent study of 99 elite academy footballers found a number of SNPs associated with bone phenotypes (trabecular density, cortical thickness and cross sectional area) using pQCT analysis. However, these associations were only observed before, but not after, a 12-week period of increased football training volume and thus no association between genotype and changes in bone parameters over time was observed. These variants included SOST rs1877632, P2RX7 rs 1718119, P2RX7 rs3751143 as well as TNFRSF11A (RANK), TNFSF11 (RANKL) and TNFRSF11B (OPG) SNPs rs9594738, rs1021188 and rs9594759 (Varley et al. 2018). Although no genotype-training interactions were observed for the SNPs analysed in this investigation, other candidate genes could be sensitive to physical loading (i.e. gene-environment interaction) and thus modulate athlete health (and, by extension, enhance endurance performance). Specifically, if an athlete has a genetic predisposition towards low BMD or elevated risk of stress fracture, exercise training and/or diet could be modified to accommodate.

\section{Genetic association with stress fracture injury}

There is a lack of conclusive evidence regarding external determinants of stress fractures (Wright et al. 2015) as mentioned in "BMD, elite athletes and injury risk". In more recent times, the idea of a proposed genetic influence has been investigated primarily in military recruits, due to the abrupt increase in training, large training volumes and high prevalence of stress fractures (Lappe et al. 2008). Examples have included the calcitonin receptor (CTR) rs1801197 and LRP5 rs2277268 polymorphisms, which were associated with femoral neck stress fractures in 72 Finnish military recruits (Korvala et al. 2010). Participants who possessed the $C T R \mathrm{C}$ allele together with a $V D R \mathrm{C}-\mathrm{A}$ haplotype were more protected from stress fractures, which may be due to the role of $C T R$ in osteoclast-mediated bone resorption (Pondel 2000).

Furthermore, larger sized CAG androgen receptor $(A R)$ gene repeats $(>16)$ were more common in Israeli military personnel who had suffered stress fractures (23\%) than those who had not suffered this injury (13\%) (Yanovich et al. 2011). A higher number of CAG repeats within the $A R$ gene are inversely associated with the transcriptional response to testosterone (Zitzmann et al. 2001) and deficiency in such hormones could influence bone metabolism and potential bone loss (Mohamad et al. 2016; Khosla 2015).

Stress fracture susceptibility, in relation to genetics, has also been investigated in athletes for the first time recently, with findings suggesting that athletes with specific genetic variants may have an increased vulnerability to this injury (Varley et al. 2015, 2016, 2017). Interestingly, three of the same SNPs (VDR FokI rs2228570, TNFSF11 rs1021188 and the loss of function $P 2 R X 7 \mathrm{rs} 3751143$ ) as mentioned above, alongside TNFRSF11A rs3018362, were associated with stress fracture incidence in the Stress Fracture in Elite Athlete (SFEA) cohort. However, a gain of function P2RX7 SNP (rs1718119) was associated with multiple stress fracture occurrence. Functional expression of purinergic receptor $\mathrm{P} 2 \mathrm{X} 7$ primarily regulates configuration of osteoclasts (Agrawal et al. 2010), as well as augmenting bone formation via a cell-autonomous role that leads to stimulation of mineralisation (Panupinthu et al. 2008), which may explain why some $P 2 R X 7$ polymorphisms have also been associated with low baseline and accelerated bone loss in post-menopausal women (Gartland et al. 2012). P2RX7 is a particularly interesting candidate gene in regard to potential gene-physical activity interactions and outcomes for BMD. Mice with a null mutation of $P 2 R X 7$ have been reported to show $>73 \%$ reduced sensitivity to mechanical loading ( $\mathrm{Li}$ et al. 2005). Fluid shear stress increased prostaglandin $(\mathrm{PG}) \mathrm{E}_{2}$ release in wild-type osteoblast cells but had no effect on $\mathrm{PGE}_{2}$ release in knockout osteoblast cells. $\mathrm{PGE}_{2}$ administration activates cortical bone modelling resulting in increased bone mass (Jee et al. 1990) and Li et al. (2005) suggested that these findings indicate ATP signalling through $P 2 R X 7$ is important for mechanically induced release of prostaglandins by bone cells and subsequent bone formation. Consequently, variation in $P 2 R X 7$ SNPs such as rs 3751143 could result in differing responses to mechanical loading and alterations to BMD, potentially influencing stress fracture susceptibility.

Although research investigating genetic influence on stress fracture has begun using the SFEA cohort, this was a loosely defined group, which comprised athletes of mixed abilities and from a range of sports. A more focussed approach, which removes the variability (i.e. loading/training patterns) introduced by incorporating athletes from different sports into one investigation, would be advantageous.

\section{Future directions and conclusions}

There are numerous polymorphisms that need further exploration vis-à-vis BMD. In particular, gene-environment (i.e. gene-physical activity) interactions are likely to contribute substantially to inter-individual differences in BMD throughout the human lifespan. Exciting findings have been observed in regard to gene-physical activity interactions and genetic associations with stress fracture, particularly in variants of pathways involved in the adaptation of bone to mechanical loading, such as the RANK/ RANKL/OPG system.

Therefore, the study of specific cohorts, who experience unusually high mechanical loads and who may display unusual bone phenotypes and/or possess genetic 
characteristics that differ from the norm, may provide novel insight into the area. Such individuals include elite athletes, who are at the extremes of human physiological capability, experience much greater environmental (mechanical) stress than most and might possess a genotype particularly suitable to tolerate those stresses.

GWAS or ideally whole genome sequencing (WGS) studies using athletic populations with their differentiating extreme phenotypes are, in principle, the next logical steps to identify key polymorphisms. Detailed study of gene function can follow. However, most GWAS designs cannot account for gene-gene/gene-environment interactions and only analyse SNPs with minor allele frequencies of more than $1 \%$, not rare variants that may lie between $0.1-1 \%$ or even lower. Thus, GWAS is appropriate for the discovery of common variants that may confer low/moderate risk but are underpowered for the detection of rare variants, which may have a large influence on a complex phenotype according to the common disease/rare variant hypothesis (Li and Leal 2008). Conducting GWAS or WGS studies is also extremely challenging due to the associated costs and difficulty in recruiting sufficiently large numbers of such a specific population. Even a panel of SNPs for investigation that is far lower in number than used in contemporary GWAS, for example, 500 SNPs, would require a sample size of 1200 to detect an effect size of 0.02 in a continuous trait, assuming $80 \%$ statistical power, a minor allele frequency of $20 \%$ and an alpha level of 0.0001 . Approximately the same size of sample would be needed for each group of a case-control study design, assuming the same parameters and an effect size (odds ratio) of up to 1.4 (Bouchard 2011).

While the large cohorts necessary for GWAS and eventually WGS studies of BMD in athletes are built, smaller samples (steps towards building the bigger sample) can be used to test hypotheses about genetic variants emerging from GWAS in relevant clinical populations. Assessing bone and injury phenotype data in those athletes will also enhance understanding of any observed genotype-phenotype relationship (Wang et al. 2013). A relatively homogenous group of athletes who experience high mechanical loads on some bone structures, such as endurance runners, would be suitable for this kind of investigation. Specifically, measuring areal BMD via DEXA scanning, with a particular emphasis on the primary loading sites in this population, would probably provide appropriate data to combat some of the challenges identified in this review. It would be fascinating to discover whether those athletes have a genotype that enhances $\mathrm{BMD}$, protects against the effects of the large volume of training required and reduces risk of stress fracture. One preliminary report (using just 14 participants) even documents an attempt to reduce the risk of tendon, ligament and bone injuries by modifying athlete training programmes based upon genetic characteristics (Goodlin et al. 2015). This illustrates the kinds of future applications possible in this field after the more fundamental research has been conducted successfully.

Author contributions AJH, AGW, SHD and GKS conceived the article ideas and drafted and revised the manuscript. PJH, RME and CS revised and edited the manuscript. All authors have read and approved the manuscript.

\section{Compliance with ethical standards}

Conflict of interest The authors declare that they have no conflict of interest.

Open Access This article is distributed under the terms of the Creative Commons Attribution 4.0 International License (http://creativeco mmons.org/licenses/by/4.0/), which permits unrestricted use, distribution, and reproduction in any medium, provided you give appropriate credit to the original author(s) and the source, provide a link to the Creative Commons license, and indicate if changes were made.

\section{References}

Ackert-Bicknell CL, Karasik D (2013) Impact of the environment on the skeleton: is it modulated by genetic factors? Curr Osteoporos Rep 11(3):219-228

Agrawal A, Buckley KA, Bowers K, Furber M, Gallagher JA, Gartland A (2010) The effects of $\mathrm{P} 2 \mathrm{X} 7$ receptor antagonists on the formation and function of human osteoclasts in vitro. Purinergic Signal 6(3):307-315

Agueda L, Urreizti R, Bustamante M, Jurado S, Garcia-Giralt N, Díez-Pérez A, Nogués X, Mellibovsky L, Grinberg D, Balcells S (2010) Analysis of three functional polymorphisms in relation to osteoporosis phenotypes: replication in a Spanish cohort. Calcif Tissue Int 87(1):14-24

Allison SJ, Poole KES, Treece GM, Gee AH, Tonkin C, Rennie WJ, Folland JP, Summers GD, Brooke-Wavell K (2015) The influence of high-impact exercise on cortical and trabecular bone mineral content and 3D distribution across the proximal femur in older men: a randomized controlled unilateral intervention. J Bone Miner Res 30(9):1709-1716

Ames SK, Ellis KJ, Gunn SK, Copeland KC, Abrams SA (1999) Vitamin D receptor gene Fok1 polymorphism predicts calcium absorption and bone mineral density in children. J Bone Miner Res 14(5):740-746

Andreoli A, Monteleone M, Van Loan M, Promenzio L, Tarantino U, De Lorenzo A (2001) Effects of different sports on bone density and muscle mass in highly trained athletes. Med Sci Sports Exerc 33(4):507-511

Appelman-Dijkstra NM, Papapoulos SE (2016) Sclerostin inhibition in the management of osteoporosis. Calcif Tissue Int 98(4):370-380

Arai H, Miyamoto KI, Taketani Y, Yamamoto H, Iemori Y, Morita K, Tonai T, Nishisho T, Mori S, Takeda E (1997) A vitamin D receptor gene polymorphism in the translation initiation codon: effect on protein activity and relation to bone mineral density in Japanese women. J Bone Miner Res 12(6):915-921

Atkins GJ, Findlay DM (2012) Osteocyte regulation of bone mineral: a little give and take. Osteoporos Int 23(8):2067-2079

Bakker AD, Jaspers RT (2015) IL-6 and IGF-1 signaling within and between muscle and bone: how important is the mTOR pathway for bone metabolism? Curr Osteoporos Rep 13(3):131-139 
Bakker AD, Kulkarni RN, Klein-Nulend J, Lems WF (2014) IL-6 alters osteocyte signaling toward osteoblasts but not osteoclasts. J Dent Res 93(4):394-399

Barnekow-Bergkvist M, Hedberg G, Pettersson U, Lorentzon R (2006) Relationships between physical activity and physical capacity in adolescent females and bone mass in adulthood. Scand J Med Sci Sports 16(6):447-455

Bass S, Pearce G, Bradney M, Hendrich E, Delmas PD, Harding A, Seeman E (1998) Exercise before puberty may confer residual benefits in bone density in adulthood: studies in active prepubertal and retired female gymnasts. J Bone Miner Res 13(3):500-507

Beck BR, Snow CM (2003) Bone health across the lifespan-exercising our options. Exerc Sport Sci Rev 31(3):117-122

Beck TJ, Ruff CB, Shaffer RA, Betsinger K, Trone DW, Brodine SK (2000) Stress fracture in military recruits: gender differences in muscle and bone susceptibility factors. Bone 27(3):437-444

Behringer M, Gruetzner S, McCourt M, Mester J (2014) Effects of weight-bearing activities on bone mineral content and density in children and adolescents: a meta-analysis. J Bone Miner Res 29(2):467-478

Bennell KL, Malcolm SA, Thomas SA, Reid SJ, Brukner PD, Ebeling PR, Wark JD (1996) Risk factors for stress fractures in track and field athletes: a twelve-month prospective study. Am J Sports Med 24(6):810-818

Bennell KL, Malcolm SA, Khan KM, Thomas SA, Reid SJ, Brukner PD, Ebeling PR, Wark JD (1997) Bone mass and bone turnover in power athletes, endurance athletes, and controls: a 12-month longitudinal study. Bone 20(5):477-484

Bennell K, Matheson G, Meeuwisse W, Brukner P (1999) Risk factors for stress fractures. Sports Med 28(2):91-122

Billat VL, Demarle A, Slawinski J, Paiva M, Koralsztein J-p (2001) Physical and training characteristics of top-class marathon runners. Med Sci Sports Exerc 33(12):2089-2097

Bonjour JP, Theintz G, Law F, Slosman D, Rizzoli R (1994) Peak bone mass. Osteoporos Int 4(1):S7-S13

Bouchard C (2011) Overcoming barriers to progress in exercise genomics. Exerc Sport Sci Rev 39(4):212

Calbet JAL, Herrera PD, Rodriguez LP (1999) High bone mineral density in male elite professional volleyball players. Osteoporos Int 10(6):468-474

Caspersen CJ, Powell KE, Christenson GM (1985) Physical activity, exercise, and physical fitness: definitions and distinctions for health-related research. Public Health Rep 100(2):126

Castelán-Martínez OD, Vivanco-Muñoz N, Falcón-Ramírez E, ValdésFlores M, Clark P (2015) Papel del polimorfismo Apa1 del gen VDR en el riesgo de osteoporosis en mujeres mexicanas posmenopáusicas. Gac Med Mex 151(4):472-476

Chang RPY, Briffa KN, Edmondston SJ (2013) Bone mineral density and body composition in elite female golf and netball players. Eur J Sport Sci 13(2):183-190

Cheung AM, Frame H, Ho M, Mackinnon ES, Brown JP (2016) Bone strength and management of postmenopausal fracture risk with antiresorptive therapies: considerations for women's health practice. Int J Women's Health 8:537

Chilibeck PD, Sale DG, Webber CE (1995) Exercise and bone mineral density. Sports Med 19(2):103-122

Clark GR, Duncan EL (2015) The genetics of osteoporosis. Br Med Bull 113(1):73-81

Colin EM, Weel AEAM, Uitterlinden AG, Buurman CJ, Birkenhäger JC, Pols HAP, Van Leeuwen JPTM (2000) Consequences of vitamin $\mathrm{D}$ receptor gene polymorphisms for growth inhibition of cultured human peripheral blood mononuclear cells by 1 , 25-dihydroxyvitamin $\mathrm{D}_{3}$. Clin Endocrinol 52(2):211-216

Cranney A, Jamal SA, Tsang JF, Josse RG, Leslie WD (2007) Low bone mineral density and fracture burden in postmenopausal women. Can Med Assoc J 177(6):575-580
Dabirnia R, Mahmazi S, Taromchi A, Nikzad M, Saburi E (2016) The relationship between vitamin $\mathrm{D}$ receptor (VDR) polymorphism and the occurrence of osteoporosis in menopausal Iranian women. Clin Cases Miner Bone Metab 13(3):190

Darling AL, Millward DJ, Torgerson DJ, Hewitt CE, Lanham-New SA (2009) Dietary protein and bone health: a systematic review and meta-analysis. Am J Clin Nutr 90(6):1674-1692

Deere K, Sayers A, Rittweger J, Tobias JH (2012) Habitual levels of high, but not moderate or low, impact activity are positively related to hip BMD and geometry: results from a populationbased study of adolescents. J Bone Miner Res 27(9):1887-1895

Ding C, Parameswaran V, Udayan R, Burgess J, Jones G (2008) Circulating levels of inflammatory markers predict change in bone mineral density and resorption in older adults: a longitudinal study. J Clin Endocrinol Metab 93(5):1952-1958

Duncan RL, Turner CH (1995) Mechanotransduction and the functional response of bone to mechanical strain. Calcif Tissue Int 57(5):344-358

Duncan CS, Blimkie CJ, Cowell CT, Burke S, Briody JN, GilesHowman R (2002) Bone mineral density in adolescent female athletes: relationship to exercise type and muscle strength. Med Sci Sports Exerc 34:286-294

Duncan EL, Danoy P, Kemp JP, Leo PJ, McCloskey E, Nicholson GC, Eastell R, Prince RL, Eisman JA, Jones G (2011) Genome-wide association study using extreme truncate selection identifies novel genes affecting bone mineral density and fracture risk. PLoS Genet 7(4):e1001372

Eriksson A-L, Suuriniemi M, Mahonen A, Cheng S, Ohlsson C (2005) The COMT val158met polymorphism is associated with early pubertal development, height and cortical bone mass in girls. Pediatr Res 58(1):71

Estrada K, Styrkarsdottir U, Evangelou E, Hsu Y-H, Duncan EL, Ntzani EE, Oei L, Albagha OME, Amin N, Kemp JP (2012) Genome-wide meta-analysis identifies 56 bone mineral density loci and reveals 14 loci associated with risk of fracture. Nat Genet 44(5):491

Fehling PC, Alekel L, Clasey J, Rector A, Stillman RJ (1995) A comparison of bone mineral densities among female athletes in impact loading and active loading sports. Bone 17(3):205-210

Ferrari SL, Deutsch S, Antonarakis SE (2005) Pathogenic mutations and polymorphisms in the lipoprotein receptor-related protein 5 reveal a new biological pathway for the control of bone mass. Curr Opin Lipidol 16(2):207-214

Fonseca H, Moreira-Gonçalves D, Coriolano H-JA, Duarte JA (2014) Bone quality: the determinants of bone strength and fragility. Sports Med 44(1):37-53

Frost HM (1990) Skeletal structural adaptations to mechanical usage (SATMU): 1. Redefining Wolff's law: the bone modeling problem. Anat Rec 226(4):403-413

Galea GL, Price JS, Lanyon LE (2013) Estrogen receptors' roles in the control of mechanically adaptive bone (re) modeling. Bonekey Rep 2:413

Gartland A, Skarratt KK, Hocking LJ, Parsons C, Stokes L, Jørgensen NR, Fraser WD, Reid DM, Gallagher JA, Wiley JS (2012) Polymorphisms in the $\mathrm{P} 2 \mathrm{X} 7$ receptor gene are associated with low lumbar spine bone mineral density and accelerated bone loss in post-menopausal women. Eur J Hum Genet 20(5):559

Golchin MM, Heidari L, Ghaderian SMH, Akhavan-Niaki H (2016) Osteoporosis: a silent disease with complex genetic contribution. J Genet Genom 43(2):49-61

Gong G, Haynatzki G (2003) Association between bone mineral density and candidate genes in different ethnic populations and its implications. Calcif Tissue Int 72(2):113-123

Goodlin GT, Roos AK, Roos TR, Hawkins C, Beache S, Baur S, Kim SK (2015) Applying personal genetic data to injury risk assessment in athletes. PLoS One 10(4):e0122676 
Gross C, Eccleshall TR, Malloy PJ, Villa ML, Marcus R, Feldman D (1996) The presence of a polymorphism at the translation initiation site of the vitamin D receptor gene is associated with low bone mineral density in postmenopausal mexican-American women. J Bone Miner Res 11(12):1850-1855

Gunter KB, Almstedt HC, Janz KF (2012) Physical activity in childhood may be the key to optimizing lifespan skeletal health. Exerc Sport Sci Rev 40(1):13

Hannam K, Deere KC, Hartley A, Al-Sari UA, Clark EM, Fraser WD, Tobias JH (2017) Habitual levels of higher, but not medium or low, impact physical activity are positively related to lower limb bone strength in older women: findings from a population-based study using accelerometers to classify impact magnitude. Osteoporos Int 28(10):2813-2822

He J, Zhang H, Wang C, Zhang Z, Yue H, Hu W, Gu J, Fu W, Hu Y, Li M (2014) Associations of serum sclerostin and polymorphisms in the SOST gene with bone mineral density and markers of bone metabolism in postmenopausal Chinese women. J Clin Endocrinol Metab 99(4):E665-E673

Heidemann M, Mølgaard C, Husby S, Schou AJ, Klakk H, Møller NC, Holst R, Wedderkopp N (2013) The intensity of physical activity influences bone mineral accrual in childhood: the childhood health, activity and motor performance school (the CHAMPS) study, Denmark. BMC Pediatr 13(1):32

Heinonen A, Oja P, Kannus P, Sievanen H, Haapasalo H, Mänttäri A, Vuori I (1995) Bone mineral density in female athletes representing sports with different loading characteristics of the skeleton. Bone 17(3):197-203

Henry YM, Fatayerji D, Eastell R (2004) Attainment of peak bone mass at the lumbar spine, femoral neck and radius in men and women: relative contributions of bone size and volumetric bone mineral density. Osteoporos Int 15(4):263-273

Hernandez CJ, Beaupre GS, Carter DR (2003) A theoretical analysis of the relative influences of peak BMD, age-related bone loss and menopause on the development of osteoporosis. Osteoporos Int 14(10):843-847

Horst-Sikorska W, Kalak R, Wawrzyniak A, Marcinkowska M, Celczynska-Bajew L, Slomski R (2007) Association analysis of the polymorphisms of the VDR gene with bone mineral density and the occurrence of fractures. J Bone Miner Metab 25(5):310-319

Horst-Sikorska W, Dytfeld J, Wawrzyniak A, Marcinkowska M, Michalak M, Franek E, Napiórkowska L, Drwęska N, Słomski R (2013) Vitamin D receptor gene polymorphisms, bone mineral density and fractures in postmenopausal women with osteoporosis. Mol Biol Rep 40(1):383-390

Hsu Y-H, Kiel DP (2012) Genome-wide association studies of skeletal phenotypes: what we have learned and where we are headed. J Clin Endocrinol Metab 97(10):E1958-E1977

Iwamoto J, Takeda T (2003) Stress fractures in athletes: review of 196 cases. J Orthop Sci 8(3):273-278

Jee WSS, Mori S, Li XJ, Chan S (1990) Prostaglandin E2 enhances cortical bone mass and activates intracortical bone remodeling in intact and ovariectomized female rats. Bone 11(4):253-266

Ji G-R, Yao M, Sun C-Y, Li Z-H, Han Z (2010) BsmI, TaqI, ApaI and FokI polymorphisms in the vitamin D receptor (VDR) gene and risk of fracture in Caucasians: a meta-analysis. Bone 47(3):681-686

Jones BH, Thacker SB, Gilchrist J, Kimsey CD Jr, Sosin DM (2002) Prevention of lower extremity stress fractures in athletes and soldiers: a systematic review. Epidemiol Rev 24(2):228-247

Kemp JP, Morris JA, Medina-Gomez C, Forgetta V, Warrington NM, Youlten SE, Zheng J, Gregson CL, Grundberg E, Trajanoska K (2017) Identification of 153 new loci associated with heel bone mineral density and functional involvement of GPC6 in osteoporosis. Nat Genet 49(10):1468
Kettunen JA, Impivaara O, Kujala UM, Linna M, Mäki J, Räty H, Alanen E, Kaprio J, Videman T, Sarna S (2010) Hip fractures and femoral bone mineral density in male former elite athletes. Bone 46(2):330-335

Khosla S (2015) New insights into androgen and estrogen receptor regulation of the male skeleton. J Bone Miner Res 30(7):1134-1137

Kiel DP, Ferrari SL, Cupples LA, Karasik D, Manen D, Imamovic A, Herbert AG, Dupuis J (2007) Genetic variation at the low-density lipoprotein receptor-related protein 5 (LRP5) locus modulates Wnt signaling and the relationship of physical activity with bone mineral density in men. Bone 40(3):587-596

Kitamura A, Hasegawa G, Obayashi H, Kamiuchi K, Ishii M, Yano M, Tanaka T, Yamaguchi M, Shigeta H, Ogata M (2002) Interleukin-6 polymorphism $(-634 \mathrm{C} / \mathrm{G})$ in the promotor region and the progression of diabetic nephropathy in Type 2 diabetes. Diabet Med 19(12):1000-1005

Koay MA, Woon PY, Zhang Y, Miles LJ, Duncan EL, Ralston SH, Compston JE, Cooper C, Keen R, Langdahl BL (2004) Influence of LRP5 polymorphisms on normal variation in BMD. J Bone Miner Res 19(10):1619-1627

Korvala J, Hartikka H, Pihlajamäki H, Solovieva S, Ruohola J-P, Sahi T, Barral S, Ott J, Ala-Kokko L, Männikkö M (2010) Genetic predisposition for femoral neck stress fractures in military conscripts. BMC Genet 11(1):95

Krall EA, Dawson-Hughes B (1993) Heritable and life-style determinants of bone mineral density. J Bone Miner Res 8(1):1-9

Krishnan V, Bryant HU, MacDougald OA (2006) Regulation of bone mass by Wnt signaling. J Clin Investig 116(5):1202-1209

Kuipers H, Keizer HA (1988) Overtraining in elite athletes. Sports Med 6(2):79-92

Lappe J, Cullen D, Haynatzki G, Recker R, Ahlf R, Thompson K (2008) Calcium and vitamin D supplementation decreases incidence of stress fractures in female navy recruits. J Bone Miner Res 23(5):741-749

Law MR, Hackshaw AK (1997) A meta-analysis of cigarette smoking, bone mineral density and risk of hip fracture: recognition of a major effect. BMJ 315(7112):841-846

Lee SH, Kang MI, Ahn SH, Lim K-H, Lee GE, Shin E-S, Lee J-E, Kim B-J, Cho E-H, Kim S-W (2014) Common and rare variants in the exons and regulatory regions of osteoporosis-related genes improve osteoporotic fracture risk prediction. J Clin Endocrinol Metab 99(11):E2400-E2411

Leonard MB, Bachrach LK (2012) Non-invasive techniques for bone mass measurement. In: Pediatric bone, biology \& diseases, 2nd edn. Elsevier, Amsterdam, pp 309-342

Levasseur R, Lacombe D, de Vernejoul MC (2005) LRP5 mutations in osteoporosis-pseudoglioma syndrome and high-bone-mass disorders. Jt Bone Spine 72(3):207-214

Li B, Leal SM (2008) Methods for detecting associations with rare variants for common diseases: application to analysis of sequence data. Am J Hum Genet 83(3):311-321

Li J, Liu D, Ke HZ, Duncan RL, Turner CH (2005) The P2X7 nucleotide receptor mediates skeletal mechanotransduction. J Biol Chem 280(52):42952-42959

Li X, He GP, Zhang B, Chen YM, Su YX (2008) Interactions of interleukin-6 gene polymorphisms with calcium intake and physical activity on bone mass in pre-menarche Chinese girls. Osteoporos Int 19(11):1629-1637

Lieben L, Carmeliet G (2013) Vitamin D signaling in osteocytes: effects on bone and mineral homeostasis. Bone 54(2):237-243

Lorentzon M, Eriksson AL, Nilsson S, Mellström D, Ohlsson C (2007) Association between physical activity and BMD in young men is modulated by catechol- $O$-methyltransferase (COMT) genotype: the GOOD study. J Bone Miner Res 22(8):1165-1172 
Loucks AB (2007) Low energy availability in the marathon and other endurance sports. Sports Med 37(4-5):348-352

Mantila Roosa SM, Liu Y, Turner CH (2011) Gene expression patterns in bone following mechanical loading. J Bone Miner Res 26(1):100-112

Marozik P, Mosse I, Alekna V, Rudenko E, Tamulaitienė M, Ramanau H, Strazdienė V, Samokhovec V, Ameliyanovich M, Byshnev N (2013) Association between polymorphisms of VDR, COL1A1, and LCT genes and bone mineral density in Belarusian women with severe postmenopausal osteoporosis. Medicina (Kaunas Lithuania) 49(4):177-184

Marti A, Martinez-González MA, Martinez JA (2008) Interaction between genes and lifestyle factors on obesity: Nutrition Society Silver Medal Lecture. Proc Nutr Soc 67(1):1-8

Martin TJ, Sims NA (2005) Osteoclast-derived activity in the coupling of bone formation to resorption. Trends Mol Med 11(2):76-81

Medina-Gomez C, Kemp JP, Estrada K, Eriksson J, Liu J, Reppe S, Evans DM, Heppe DHM, Vandenput L, Herrera L (2012) Metaanalysis of genome-wide scans for total body BMD in children and adults reveals allelic heterogeneity and age-specific effects at the WNT16 locus. PLoS Genet 8(7):e1002718

Milner CE, Ferber R, Pollard CD, Hamill J, Davis IS (2006) Biomechanical factors associated with tibial stress fracture in female runners. Med Sci Sports Exerc 38(2):323-328

Mitchell JA, Chesi A, Elci O, McCormack SE, Roy SM, Kalkwarf HJ, Lappe JM, Gilsanz V, Oberfield SE, Shepherd JA (2016) Physical activity benefits the skeleton of children genetically predisposed to lower bone density in adulthood. J Bone Miner Res 31(8):1504-1512

Mizuguchi T, Furuta I, Watanabe Y, Tsukamoto K, Tomita H, Tsujihata M, Ohta T, Kishino T, Matsumoto N, Minakami H (2004) LRP5, low-density-lipoprotein-receptor-related protein 5, is a determinant for bone mineral density. J Hum Genet 49(2):80-86

Mohamad N-v, Soelaiman I-N, Chin K-Y (2016) A concise review of testosterone and bone health. Clin Interv Aging 11:1317

Moran JM, Rodriguez-Velasco FJ, Roncero-Martin R, Rey-Sanchez P, Martinez M, Pedrera-Zamorano JD (2014) The relationship between polymorphisms in the vitamin $\mathrm{D}$ receptor gene and bone mineral density in postmenopausal women. ISRN Genet 2014:549457

Moran JM, Pedrera-Canal M, Rodriguez-Velasco FJ, Vera V, LavadoGarcia JM, Fernandez P, Pedrera-Zamorano JD (2015) Lack of association of vitamin D receptor BsmI gene polymorphism with bone mineral density in Spanish postmenopausal women. PeerJ 3:e953

Morseth B, Emaus N, Wilsgaard T, Jacobsen BK, Jørgensen L (2010) Leisure time physical activity in adulthood is positively associated with bone mineral density 22 years later. The Troms $\varnothing$ study. Eur J Epidemiol 25(5):325-331

Mudd LM, Fornetti W, Pivarnik JM (2007) Bone mineral density in collegiate female athletes: comparisons among sports. J Athl Train 42(3):403

Munafo MR, Clark TG, Flint J (2004) Assessing publication bias in genetic association studies: evidence from a recent meta-analysis. Psychiatry Res 129(1):39-44

Nakamura O, Ishii T, Ando Y, Amagai H, Oto M, Imafuji T, Tokuyama $\mathrm{K}$ (2002a) Potential role of vitamin D receptor gene polymorphism in determining bone phenotype in young male athletes. $\mathrm{J}$ Appl Physiol 93(6):1973-1979

Nakamura O, Ishii T, Mankyu H, Tsubakimoto S, Nomura T, Tokuyama K (2002b) Contribution of vitamin D receptor genotypes to bone mineral density in young male athletes with different impact loading. Eur J Sport Sci 2(2):1-8

Nakashima T, Hayashi M, Fukunaga T, Kurata K, Oh-Hora M, Feng JQ, Bonewald LF, Kodama T, Wutz A, Wagner EF (2011)
Evidence for osteocyte regulation of bone homeostasis through RANKL expression. Nat Med 17(10):1231

Neville CE, Murray LJ, Boreham CAG, Gallagher AM, Twisk J, Robson PJ, Savage JM, Kemper HCG, Ralston SH, Smith GD (2002) Relationship between physical activity and bone mineral status in young adults: the Northern Ireland Young Hearts Project. Bone 30(5):792-798

Ni Y, Li H, Zhang Y, Zhang H, Pan Y, Ma J, Wang L (2014) Association of IL-6 G-174C polymorphism with bone mineral density. J Bone Miner Metab 32(2):167-173

Nieves JW, Melsop K, Curtis M, Kelsey JL, Bachrach LK, Greendale G, Sowers MF, Sainani KL (2010) Nutritional factors that influence change in bone density and stress fracture risk among young female cross-country runners. PM\&R 2(8):740-750

Ondrak KS, Morgan DW (2007) Physical activity, calcium intake and bone health in children and adolescents. Sports Med 37(7):587-600

Ostrowski K, Schjerling P, Pedersen BK (2000) Physical activity and plasma interleukin-6 in humans - effect of intensity of exercise. Eur J Appl Physiol 83(6):512-515

Ott SM, O'Hanlan M, Lipkin EW, Newell-Morris L (1997) Evaluation of vertebral volumetric vs. areal bone mineral density during growth. Bone 20(6):553-556

Panupinthu N, Rogers JT, Zhao L, Solano-Flores LP, Possmayer F, Sims SM, Dixon SJ (2008) P2X7 receptors on osteoblasts couple to production of lysophosphatidic acid: a signaling axis promoting osteogenesis. J Cell Biol 181(5):859-871

Pettersson U, Nilsson M, Sundh V, Mellström D, Lorentzon M (2010) Physical activity is the strongest predictor of calcaneal peak bone mass in young Swedish men. Osteoporos Int 21(3):447-455

Pluijm SMF, Visser M, Smit JH, Popp-Snijders C, Roos JC, Lips P (2001) Determinants of bone mineral density in older men and women: body composition as mediator. J Bone Miner Res 16(11):2142-2151

Pollock N, Grogan C, Perry M, Pedlar C, Cooke K, Morrissey D, Dimitriou L (2010) Bone-mineral density and other features of the female athlete triad in elite endurance runners: a longitudinal and cross-sectional observational study. Int J Sport Nutr Exerc Metab 20(5):418-426

Pondel M (2000) Calcitonin and calcitonin receptors: bone and beyond. Int J Exp Pathol 81(6):405-422

Prince SA, Adamo KB, Hamel ME, Hardt J, Gorber SC, Tremblay M (2008) A comparison of direct versus self-report measures for assessing physical activity in adults: a systematic review. Int J Behav Nutr Phys Act 5(1):56

Ralston SH, de Crombrugghe B (2006) Genetic regulation of bone mass and susceptibility to osteoporosis. Genes Dev 20(18):2492-2506

Ralston SH, Uitterlinden AG (2010) Genetics of osteoporosis. Endocr Rev 31(5):629-662

Ranson CA, Burnett AF, Kerslake RW (2010) Injuries to the lower back in elite fast bowlers: acute stress changes on MRI predict stress fracture. Bone Jt J 92(12):1664-1668

Richards JB, Zheng H-F, Spector TD (2012) Genetics of osteoporosis from genome-wide association studies: advances and challenges. Nat Rev Genet 13(8):576

Riggs LB, Nguyen TV, Melton JL, Morrison NA, O'Fallon WM, Kelly PJ, Egan KS, Sambrook PN, Muhs JM, Eisman JA (1995) The contribution of vitamin $\mathrm{D}$ receptor gene alleles to the determination of bone mineral density in normal and osteoporotic women. J Bone Miner Res 10(6):991-996

Riggs BL, Melton LJ, Robb RA, Camp JJ, Atkinson EJ, McDaniel L, Amin S, Rouleau PA, Khosla S (2008) A population-based assessment of rates of bone loss at multiple skeletal sites: evidence for substantial trabecular bone loss in young adult women and men. J Bone Miner Res 23(2):205-214 
Robinson JA, Chatterjee-Kishore M, Yaworsky PJ, Cullen DM, Zhao W, Li C, Kharode Y, Sauter L, Babij P, Brown EL (2006) Wnt/ $\beta$-catenin signaling is a normal physiological response to mechanical loading in bone. J Biol Chem 281(42):31720-31728

Sanchez C, Gabay O, Salvat C, Henrotin YE, Berenbaum F (2009) Mechanical loading highly increases IL-6 production and decreases OPG expression by osteoblasts. Osteoarthr Cartil 17(4):473-481

Santos L, Elliott-Sale KJ, Sale C (2017) Exercise and bone health across the lifespan. Biogerontology 18(6):931-946

Schoenau E, Neu CM, Beck B, Manz F, Rauch F (2002) Bone mineral content per muscle cross-sectional area as an index of the functional muscle-bone unit. J Bone Miner Res 17(6):1095-1101

Scofield KL, Hecht S (2012) Bone health in endurance athletes: runners, cyclists, and swimmers. Curr Sports Med Rep 11(6):328-334

Sharma G, Sharma AR, Seo E-M, Nam J-S (2015) Genetic polymorphism in extracellular regulators of Wnt signaling pathway. BioMed Res Int 2015:847529

Slemenda CW, Miller JZ, Hui SL, Reister TK, Johnston CC (1991) Role of physical activity in the development of skeletal mass in children. J Bone Miner Res 6(11):1227-1233

Snyder RA, Koester MC, Dunn WR (2006) Epidemiology of stress fractures. Clin Sports Med 25(1):37-52

Steeve KT, Marc P, Sandrine T, Dominique H, Yannick F (2004) IL-6, RANKL, TNF-alpha/IL-1: interrelations in bone resorption pathophysiology. Cytokine Growth Factor Rev 15(1):49-60

Strope MA, Nigh P, Carter MI, Lin N, Jiang J, Hinton PS (2015) Physical activity-associated bone loading during adolescence and young adulthood is positively associated with adult bone mineral density in men. Am J Men's Health 9(6):442-450

Styrkarsdottir U, Thorleifsson G, Gudjonsson SA, Sigurdsson A, Center JR, Lee SH, Nguyen TV, Kwok TCY, Lee JSW, Ho SC (2016) Sequence variants in the PTCH1 gene associate with spine bone mineral density and osteoporotic fractures. Nat Commun 7:10129

Takács I, Lazáry Á, Kósa JP, Kiss J, Balla B, Nagy Z, Bácsi K, Speer G, Lakatos P (2010) Allelic variations of RANKL/OPG signaling system are related to bone mineral density and in vivo gene expression. Eur J Endocrinol 162(2):423-431

Tobias JH (2014) Physical activity and bone: may the force be with you. Front Endocrinol 5:20

Tommasini SM, Nasser P, Schaffler MB, Jepsen KJ (2005) Relationship between bone morphology and bone quality in male tibias: implications for stress fracture risk. J Bone Miner Res 20(8):1372-1380

Torstveit MK, Sundgot-Borgen J (2005) Low bone mineral density is two to three times more prevalent in non-athletic premenopausal women than in elite athletes: a comprehensive controlled study. Br J Sports Med 39(5):282-287

Troiano RP, McClain JJ, Brychta RJ, Chen KY (2014) Evolution of accelerometer methods for physical activity research. Br J Sports 48:1019-1023

Tveit M, Rosengren BE, Nilsson J, Ahlborg HG, Karlsson MK (2013) Bone mass following physical activity in young years: a mean 39-year prospective controlled study in men. Osteoporos Int 24(4):1389-1397

Tyrovola JB, Odont XX (2015) The "mechanostat theory" of frost and the OPG/Rankl/RANK system. J Cell Biochem 116(12):2724-2729

Uitterlinden AG, Fang Y, van Meurs JBJ, Pols HAP, van Leeuwen JPTM (2004) Genetics and biology of vitamin D receptor polymorphisms. Gene 338(2):143-156
Valdimarsson Ö, Kristinsson J, Stefansson S, Valdimarsson S, Sigurdsson G (1999) Lean mass and physical activity as predictors of bone mineral density in 16-20-year old women. J Intern Med 245(5):489-496

Varley I, Hughes DC, Greeves JP, Stellingwerff T, Ranson C, Fraser WD, Sale C (2015) RANK/RANKL/OPG pathway: genetic associations with stress fracture period prevalence in elite athletes. Bone 71:131-136

Varley I, Greeves JP, Sale C, Friedman E, Moran DS, Yanovich R, Wilson PJ, Gartland A, Hughes DC, Stellingwerff T (2016) Functional polymorphisms in the $\mathrm{P} 2 \mathrm{X} 7$ receptor gene are associated with stress fracture injury. Purinergic Signal 12(1):103-113

Varley I, Hughes DC, Greeves JP, Stellingwerff T, Ranson C, Fraser WD, Sale C (2017) The association of novel polymorphisms with stress fracture injury in Elite Athletes: further insights from the SFEA cohort. J Sci Med Sport. https://doi. org/10.1016/j.jsams.2017.10.038

Varley I, Hughes DC, Greeves JP, Fraser WD, Sale C (2018) SNPs in the vicinity of P2X7R, RANK/RANKL/OPG and Wnt signalling pathways and their association with bone phenotypes in academy footballers. Bone 108:179-185

Velez NF, Zhang A, Stone B, Perera S, Miller M, Greenspan SL (2008) The effect of moderate impact exercise on skeletal integrity in master athletes. Osteoporos Int 19(10):1457-1464

Walsh JS, Henry YM, Fatayerji D, Eastell R (2009) Lumbar spine peak bone mass and bone turnover in men and women: a longitudinal study. Osteoporos Int 20(3):355-362

Wang G, Padmanabhan S, Wolfarth B, Fuku N, Lucia A, Ahmetov II, Cieszczyk P, Collins M, Eynon N, Klissouras V, Williams AG, Pitsiladis, Y (2013) Genomics of elite sporting performance: what little we know and necessary advances. In: Advances in genetics, vol 84. Elsevier, Amsterdam, pp 123-149

Warburton DER, Nicol CW, Bredin SSD (2006) Health benefits of physical activity: the evidence. Can Med Assoc J 174(6):801-809

Warden SJ, Roosa SMM, Kersh ME, Hurd AL, Fleisig GS, Pandy MG, Fuchs RK (2014) Physical activity when young provides lifelong benefits to cortical bone size and strength in men. Proc Natl Acad Sci 111(14):5337-5342

Weaver CM, Gordon CM, Janz KF, Kalkwarf HJ, Lappe JM, Lewis R, O'Karma M, Wallace TC, Zemel BS (2016) The National Osteoporosis Foundation's position statement on peak bone mass development and lifestyle factors: a systematic review and implementation recommendations. Osteoporos Int 27(4):1281-1386

Weeks BK, Young CM, Beck BR (2008) Eight months of regular in-school jumping improves indices of bone strength in adolescent boys and girls: the POWER PE study. J Bone Miner Res 23(7):1002-1011

Whitfield GP, Kohrt WM, Gabriel KKP, Rahbar MH, Kohl Iii HW (2015) Bone mineral density across a range of physical activity volumes: NHANES 2007-2010. Med Sci Sports Exerc 47(2):326

Wright AA, Taylor JB, Ford KR, Siska L, Smoliga JM (2015) Risk factors associated with lower extremity stress fractures in runners: a systematic review with meta-analysis. Br J Sports Med 49(23):1517-1523

Wright AA, Hegedus EJ, Lenchik L, Kuhn KJ, Santiago L, Smoliga JM (2016) Diagnostic accuracy of various Imaging modalities for suspected lower extremity stress fractures. Am J Sports Med 44(1):255-263

Xu H, Xiong DH, Xu FH, Zhang YY, Lei SF, Deng HW (2005) Association between VDR ApaI polymorphism and hip bone mineral density can be modified by body mass index: a study 
on postmenopausal Chinese women. Acta Biochim Biophys Sin 37(1):61-67

Yan L, Hu R, Tu S, Cheng WJ, Zheng Q, Wang JW, Kan WS, Ren YJ (2015) Meta-analysis of association between IL6-634C/G polymorphism and osteoporosis. Genet Mol Res 14(4):19225-19232

Yanovich R, Milgrom R, Friedman E, Moran DS (2011) Androgen receptor CAG repeat size is associated with stress fracture risk: a pilot study. Clin Orthop Relat Res 469(10):2925-2931
Zitzmann M, Brune M, Kornmann B, Gromoll J, Junker R, Nieschlag E (2001) The CAG repeat polymorphism in the androgen receptor gene affects bone density and bone metabolism in healthy males. Clin Endocrinol 55(5):649-657

\section{Affiliations}

\section{Adam J. Herbert ${ }^{1}$ (D) Alun G. Williams ${ }^{2,5}$. Philip J. Hennis ${ }^{3} \cdot$ Robert M. Erskine $^{4,5} \cdot$ Craig Sale $^{3} \cdot$ Stephen H. Day ${ }^{6}$. Georgina K. Stebbings ${ }^{2}$}

Alun G. Williams

a.g.williams@mmu.ac.uk

Philip J. Hennis

philip.hennis@ntu.ac.uk

Robert M. Erskine

r.m.erskine@ljmu.ac.uk

Craig Sale

craig.sale@ntu.ac.uk

Stephen H. Day

stephen.day@wlv.ac.uk

Georgina K. Stebbings

g.stebbings@mmu.ac.uk

1 Department of Sport and Exercise, School of Health Sciences, Faculty of Health, Education and Life Sciences, Birmingham City University, Birmingham, UK
2 Sports Genomics Laboratory, Manchester Metropolitan University, Cheshire Campus, Crewe Green Road, Crewe CW1 5DU, UK

3 Musculoskeletal Physiology Research Group, Sport, Health and Performance Enhancement Research Centre, Nottingham Trent University, Clifton Lane, Clifton, Nottingham NG11 8NS, UK

4 Research Institute for Sport and Exercise Sciences, Liverpool John Moores University, Byrom Street, Liverpool L3 3AF, UK

5 Institute of Sport, Exercise and Health, University College London, Tottenham Court Road, London W17 7HA, UK

6 Department of Biomedical Science \& Physiology, School of Sciences, Faculty of Science and Engineering, University of Wolverhampton, Wolverhampton, UK 